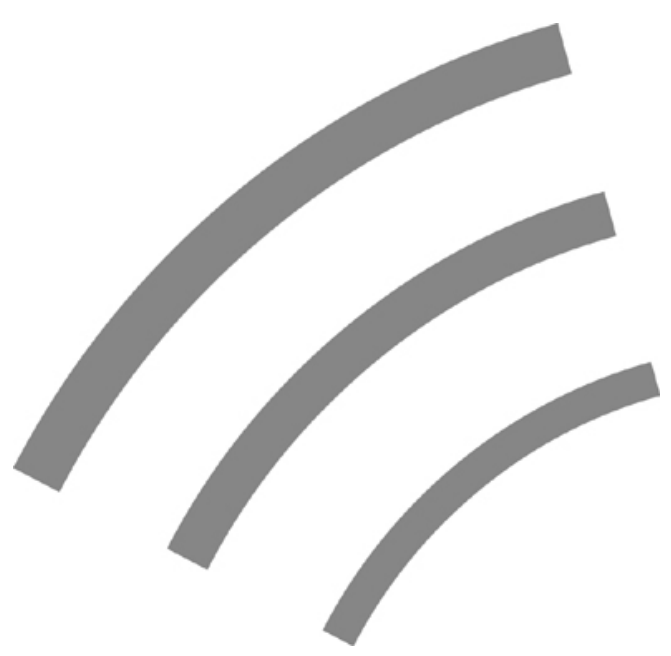

SCALES-paper N200312

\title{
BUSINESS ACCOMPLISHMENTS, GENDER AND ENTREPRENEURIAL SELF-IMAGE
}

Ingrid Verheul

Lorraine Uhlaner

Roy Thurik

Zoetermeer, October, 2003 
The SCALES-paper series is an electronic working paper series of EIM Business and Policy Research. The SCALES-initiative (Scientific Analysis of Entrepreneurship and SMEs) is part of the 'SMEs and Entrepreneurship' programme, financed by the Netherlands' Ministry of Economic Affairs. Complete information on this programme can be found at www.eim.nl/smes-and-entrepreneurship

The papers in the SCALES-series report on ongoing research at EIM. The information in the papers may be (1) background material to regular EIM Research Reports, (2) papers presented at international academic conferences, (3) submissions under review at academic journals. The papers are directed at a research-oriented audience and intended to share knowledge and promote discussion on topics in the academic fields of small business economics and entrepreneurship research.

$\begin{array}{ll}\text { address: } & \text { Italiëlaan } 33 \\ \text { mail address: } & \text { P.O. Box } 7001 \\ & \text { 2701 AA Zoetermeer } \\ \text { telephone: } & +31793413634 \\ \text { telefax: } & +31793415024 \\ \text { website: } & \text { www.eim.nl }\end{array}$

The responsibility for the contents of this report lies with EIM. Quoting numbers or text in papers, essays and books is permitted only when the source is clearly mentioned. No part of this publication may be copied and/or published in any form or by any means, or stored in a retrieval system, without the prior written permission of EIM.

EIM does not accept responsibility for printing errors and/or other imperfections. 


\section{BUSINESS ACCOMPLISHMENTS, GENDER AND ENTREPRENEURIAL SELF-IMAGE}

Ingrid Verheul, Lorraine Uhlaner and Roy Thurik

Centre for Advanced Small Business Economics (CASBEC) and European Family Business Institute (EFBI), Rotterdam School of Economics, Erasmus University Rotterdam, P.O. Box 1738, 3000 DR Rotterdam, the Netherlands, tel. +31104081398 , fax. +31104089146 and

EIM Business and Policy Research, P.O. Box 7001, 2701 AA Zoetermeer, the Netherlands, tel. +31793413634

E-mail: verheul@,few.eur.nl, uhlaner@,few.eur.nl and thurik@few.eur.nl

\section{ACKNOWLEDGEMENT}

The present study is based on a scale of entrepreneurial activity proposed by Karl H. Vesper at the USASBE conference, San Diego, California, January 1999. The authors would like to thank Karl Vesper, Siah Hwee Ang, Charles Baden-Fuller, Maryse Brand, Hans Bruining, Martin Carree, Per Davidsson, Dylan Jones-Evans, Marco van Gelderen, Antti Haahti, the editor of this journal and two anonymous referees for their helpful comments on an earlier version. Ingrid Verheul acknowledges financial support of the Fund Schiedam Vlaardingen e.o. and the Trust Fund Rotterdam. Lorraine Uhlaner acknowledges financial support of Arenthals Grant Thornton accountants and advisors, Fortis Bank, and MeesPierson Bank. Earlier versions of the present paper have been read at the ERIM conference "New Organizational Forms", Erasmus University Rotterdam, The Netherlands, November 2001; the RENT XV Conference, Turku, Finland, November 2001; the SBEDC conference, Nottingham, United Kingdom, April 2002; the Babson BKERC conference, Boulder, Colorado, June 2002; and the ICSB world conference, San Juan, Puerto Rico, June 2002. 
BUSINESS ACCOMPLISHMENTS, GENDER AND ENTREPRENEURIAL SELFIMAGE

\begin{abstract}
Drawing on Bem's psychological theory of self-perception, this paper presents and tests a model that examines the impact of business accomplishments and gender on entrepreneurial self-image and explores the definition of entrepreneurship according to Vesper's Entrepreneurial Typology. Regression techniques are used to identify those business accomplishments that university alumni associate with self-perceptions of entrepreneurship. Experience as a small business person (founding, running, and/or owning a small business) most clearly predicts entrepreneurial self-image. Results also support predictions of both direct and indirect effects of gender as well as direct effects of education and business degree. Results of a separate expert panel study are used to rank business accomplishments according to degree of entrepreneurship. Results of both studies reveal stark contrasts in the implied definition of entrepreneurship between entrepreneurship experts (academic and practitioner alike) and the general business community (as represented by the alumni). This raises questions about the meaning of the term "entrepreneurship", what the word "entrepreneur", in particular, conveys to the general public, and the implications for practice and future research.
\end{abstract}




\section{BUSINESS ACCOMPLISHMENTS, GENDER AND ENTREPRENEURIAL SELF- IMAGE}

\section{INTRODUCTION}

The present paper is motivated in part by the following question: "What is an entrepreneur?". This seemingly simple question, which is likely to be asked numerous times to most of our readers in the course of their professional work, continues to spark debate and disagreement within the scholarly community. The present paper is neither intended nor is likely to end that debate. However, it does attempt to provide new insights about the way in which the term "entrepreneur" is perceived by members of the general business community (i.e., business people) and how this perception compares to that of entrepreneurship specialists (i.e., academics, policy makers or other professionals active in the field of entrepreneurship). The outcomes of our research are not meant necessarily to be used to further define the scholarly domain of entrepreneurship, i.e., what entrepreneurship researchers should study in order to gain knowledge about this phenomenon (see Davidsson, 2003). However, our results may help to clarify what the general business community and perhaps society-at-large, may be thinking about when we use the term "entrepreneur", thus expediting communication between scholars and those groups ${ }^{1}$.

To further our understanding of the popular view of the concept of "entrepreneur", the primary research question of this paper is as follows: "Do certain characteristics of individuals influence their entrepreneurial self-image, i.e., the extent to which they perceive themselves to be entrepreneurs?" The primary set of characteristics, the respondent's business accomplishments, is derived from a typology of entrepreneurial activities proposed by Vesper (Vesper, 1999). Though grounded in social-psychological research, unique to this study is the focus of the direct influence of business behaviors on entrepreneurial self-perceptions, as well as the influence of gender on those self-perceptions.

In order to validate the set of business accomplishments used in our study to represent activities with entrepreneurial potential, we include an expert panel study to supplement the review of the entrepreneurship behavior literature. Although one can argue that there is a two-way relationship between business accomplishments and entrepreneurial self-image, the focus in 
the present paper is on the influence of behavior on entrepreneurial self-image. From a theoretical perspective, our study is a new application of well-established psychological theories linking behavior and perception (James, 1890, 1950; Bem, 1972; Bandura, 1977, 1986). Moreover, to our knowledge, this is the first time that Vesper's (1999) entrepreneurial typology is tested and used in empirical research.

Gender is a second individual characteristic used to predict entrepreneurial self-image. At the macro level, female and male entrepreneurs appear to differ with respect to the type of entrepreneurial activity they engage in and the way in which they manage this activity (Verheul and Thurik, 2001; U.S. Small Business Administration, 1995; OECD, 1998; Carter et al, 1997; Kalleberg and Leicht, 1991; Fischer et al., 1993). In addition, the management literature indicates that, as compared to men, women tend to underrate their own performance (Wohlers and London, 1989; Lindeman et al., 1995). Accordingly, we expect to find an indirect effect of gender (through entrepreneurial activity) on entrepreneurial self-image, as well as a direct gender effect (controlling for entrepreneurial activity). Several control variables, including age, education level and business education, are also examined for possible effects on entrepreneurial self-image.

\section{Structure of the Paper}

The paper is structured as follows. First, we introduce the concept of (entrepreneurial) selfperception and its relationship to business behaviors. Within this section, we elaborate on the theories linking behavior and self-perception. Second, we provide an overview of business accomplishments or behaviors that are classified as entrepreneurial in the literature, including a discussion of Vesper's Entrepreneurial Typology. Using Vesper's Entrepreneurial Typology, we propose a ranking of business accomplishments according to the degree of entrepreneurship based on the extant literature. Subsequently, we review the literature regarding the relationship between gender and entrepreneurship, including business behaviors as well as entrepreneurial self-image. On the basis of the theoretical discussion, we introduce a model and hypotheses for explaining entrepreneurial self-perception from activity and gender.

In the following section we discuss the methodology and results for validating the proposed ranking of business accomplishments according to degree of entrepreneurship, based on the views of 162 respondents in an expert panel survey. Next, we present the methodology and

\footnotetext{
${ }^{1}$ Some researchers may wish to further consider these multiple perspectives in light of the scientific paradigm of realism; i.e. the view that even though there is a "real" world to discover, it can only be comprehended imperfectly via investigation and triangulation from different viewpoints or data sources (Healy and Perry, 2000).
} 
results for testing the model and hypotheses with an exploratory study, based on a nonrandom data sample of 207 alumni of a large Midwestern U.S. university. Final sections present discussion of the results, directions for future research and conclusions.

\section{BUSINESS BEHAVIORS AND ENTREPRENEURIAL SELF-PERCEPTION}

This paper draws upon the world of self-concept. According to William James (1890, 1950), the 'empirical self', consisting of a material, social and spiritual component, is the key to understanding the experience of individuals ${ }^{2}$. In the present paper it is argued that people come to know themselves by drawing information from their own behavior.

According to social learning theory, Bandura $(1977,1986)$ argues that there is triadic reciprocal causation among behavior, cognitive and other personal factors and the environment. This means that on the one hand the environment and the perception of both this environment and self by an individual can influence the individual's behavior. On the other hand, the behavior of an individual influences the environment as well as the way in which he or she perceives of him- or herself and the environment ${ }^{3}$. In addition to Bandura, in the psychology literature Bem (1972) provides evidence of behavioral influences on self-perception. More specifically, Bem's self-perception theory states that: “individuals come to 'know' their own attitudes, emotions and other internal states partially by inferring them from observations of their own overt behavior and / or the circumstances in which this behavior occurs" (Bem, 1972, p. 5).

The relationship between entrepreneurial activity and perception has been studied mainly from the viewpoint that perception influences entrepreneurial activity (Boyd and Vozikis, 1994; Scherer et al., 1990 and 1989; Krueger and Brazeal, 1994; Krueger, 1993; Chen et al., 1998). These studies focus upon and refer to the concept of self-efficacy as the perceived personal ability to perform a given task. In that context it has been suggested that individuals make career choices based upon their perception of and the associated fit with a certain profession (Fagenson and Marcus, 1991). Chen et al. (1998, p. 297) argue that “ ... they assess their personal capabilities against the requirements of different occupations". The choice to engage in entrepreneurial activity is thus interpreted as dependent upon whether individuals can identify with the characteristics and behaviors that are associated with entrepreneurship.

\footnotetext{
${ }^{2}$ See Smith (1992) for a detailed discussion of William James's theory of self.

3 "This reciprocality does not mean that the different influences are of equal strength" (Wood and Bandura, 1989, p. 362).
} 
In the present study we take the opposite perspective and explain entrepreneurial selfperception by way of prior business accomplishments (which may vary in the degree to which they are perceived as being entrepreneurial by different individuals). Though Bem's selfperception theory has been used extensively in other types of research applications ${ }^{4}$ within the field of entrepreneurship relatively few empirical studies have focused upon explaining entrepreneurial self-perception from behavior. However, van Gelderen (2000) provides some evidence to support the claim that entrepreneurial behavior influences self-perception. His study investigates what people consider entrepreneurial about their behavior.

\section{DEFINITIONS AND TYPOLOGIES OF ENTREPRENEURIAL BEHAVIORS}

Definitions of entrepreneurship vary widely (Hébert and Link, 1989; Van Praag, 1999; Lumpkin and Dess, 1996). Kaufmann and Dant (1998) identify the following three classes of definitions: (1) those based on traits or qualities; (2) those based on the role or function of the entrepreneur in the economic process; and (3) those based on the behavior or activities of entrepreneurs. For the purpose of our paper we take a behavioral approach to studying entrepreneurship, consistent with the mainstream scholarly perspective (Gartner, 1990).

\section{Entrepreneurial Behavior or Activities}

A wide range of business behaviors has variously been classified in the literature as "entrepreneurial", including starting a business (i.e., new venture creation), innovation, business ownership, business growth and size achievement, and managing a large business. In this section we will make a distinction between these different types of entrepreneurial activity.

Early on in the development of the field of entrepreneurship, many scholars propagated the view that new venture creation is at the heart of entrepreneurship (Chandler, 1990; Gartner, 1990, 1989, 1985; Low and MacMillan, 1988; McClelland, 1961; Schumpeter, 1934; Vesper, 1980). Two problems that arise with this view is that not all new ventures pursue growth (Carland et al., 1984; Dunkelberg and Cooper, 1982) or innovation (Hornaday, 1992, Schumpeter, 1934), although these two issues are considered by many as added essential components of entrepreneurial behavior.

\footnotetext{
${ }^{4}$ Self-perception theory has been applied extensively to social scientific research since the mid 1970's but primarily to empirical research in applied social psychology (Dolinski, 2000; Uranowitz, 1975; Weiner, 1974) and clinical psychology (Robak, 2001; Schnall, Abrahamson and Laird, 2002; Haemmerlie and Montgomery, 1987). It has been compared and contrasted with cognitive dissonance theory to explain human attitudes (Weiner, 1974). Self-perception theory has been applied not only to physical but also cognitive behaviors on selfperception (see Damrad-Frye and Laird, 1989). Studies generally confirm predictions derived from the theory.
} 
Building on the concept of "newness", but recognizing the need to view entrepreneurial behavior more broadly, Gartner et al. (1989) argue that most studies of new venture creation tend to ignore that there are other ways to achieve business ownership than through starting a new business from scratch, for instance through the acquisition of an established business. Cooper and Dunkelberg (1986) also distinguish between different paths to business ownership, including starting a new business, purchasing or inheriting a business and being promoted or brought in by existing owners. Building on these notions, Lumpkin and Dess (1996) argue that "the essential act of entrepreneurship is new entry" (p.136), defining new entry as "entering new or established markets with new or existing goods or services". This can be achieved "by starting a business, through an existing business or internal corporate venturing" (Lumpkin and Dess, 1996, p. 136). Implicit in this definition of new entry is the notion that entrepreneurship can exist within large businesses. This type of entrepreneurship is often referred to as corporate entrepreneurship or intrapreneurship where new ideas and responsibilities are implemented in existing, large businesses (Wennekers and Thurik, 1999; Stopford and Baden-Fuller, 1994; and Stevenson and Jarillo, 1990). In this respect "entrepreneurial activities in existing, large firms often take place by mimicking smallness" and "entrepreneurship occurs irrespective of firm size" (Wennekers and Thurik, 1999, p. 33). Other researchers even argue that managing a business is an entrepreneurial activity. According to McClelland (1965) managers can display entrepreneurial behavior in their wage jobs by taking responsibility for their actions and decisions and creatively solve problems. Moreover, Brandstätter (1997) stresses that entrepreneurial behavior is important in all leading positions within the higher level of organizations.

\section{Vesper's Entrepreneurial Typology}

In his keynote address at the 1999 Conference of the United States Association for Small Business and Entrepreneurship (USASBE), Karl Vesper proposes an entrepreneurial typology, embracing a broad range of these themes in entrepreneurial behavior (Vesper, 1999). See Table 1. Vesper does not try to rank these activities, but instead acknowledges that different types of entrepreneurial activity exist side by side (see also Cunningham and Lischeron, 1991). Vesper argues that researchers should adopt a view that separately identifies different types of entrepreneurs rather than solving the conundrum: "What is an entrepreneur"?

More recently, it has been applied to research in marketing and consumer behavior research (Forehand, 1998; Laverie et al., 2002) . 
Table 1 here

\section{Degree of Entrepreneurship}

Although Vesper does not put forward a ranking of the proposed activities, it is plausible that the different types of entrepreneurial activity are perceived to involve a different 'degree of entrepreneurship', a concept first proposed by Cooper and Dunkelberg (1986). In particular, different activities may vary in degree of entrepreneurship depending upon underlying requirements or characteristics, such as opportunity perception (Kirzner, 1979), imagination (Shackle, 1979), creativity (Torrance, 1967), innovation (Schumpeter, 1934), risk-taking (Knight, 1921; Cantillon, 193; Hull et al, 1980; Sexton and Bowman, 1985, 1986; Stewart et

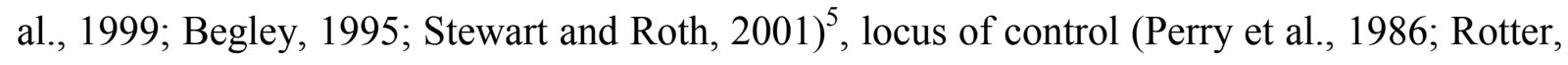
1966), need for achievement (McClelland, 1961; Perry et al., 1986), need for autonomy, initiative and persistence.

Of the underlying characteristics, Cooper and Dunkelberg (1986) single out opportunity perception, risk-taking and innovation (as a creative process) as most relevant. The selection of these three characteristics is consistent with results in Gartner's (1990) study of the perceptions of the concept of entrepreneurship by experts ${ }^{6}$. For these reasons, we have selected risktaking, innovation and opportunity perception as initial indicators for degree of entrepreneurship. In the remainder of this section we successively review the way in which these three characteristics relate to several of the activities listed in Vesper's Entrepreneurial Typology and the other activities we included from the literature. At the end of this section, we present a summary table providing an initial rank ordering according to our interpretation of the literature.

\section{Founding a firm from "scratch"}

New venture creation, i.e., founding a firm from scratch (without any past history or linkage to a parent company), is often viewed as involving the highest degree of entrepreneurship. Founding a firm involves both the processes of perceiving an opportunity and acting upon the

\footnotetext{
5 Note however that other research on risk-taking has posits that risk-taking propensity is not a distinctive feature of entrepreneurship. See, for instance, the work by Brockhaus (Brockhaus and Nord, 1979; Brockhaus, 1980; Brockhaus et al., 1986).

${ }^{6}$ In particular, six of the twelve items most highly correlated with the first factor, "The Entrepreneur", representing 17.4 percent of the variance in the analysis, mention risk. The second factor relates to and is labeled "Innova-
} 
perceived opportunity (Kirzner, 1979). It involves innovation because something is created where nothing existed previously and resources are combined in a new way (Cooper and Dunkelberg, 1986). According to Carland et al. (1984) an entrepreneurial venture is in principle characterized by innovative practices ${ }^{7}$. In addition, the founder is willing to personally absorb the risks involved in starting a new business (Cooper and Dunkelberg, 1986). Several scholars further argue that founders show higher risk-taking than non-founders (Begley, 1995; Begley and Boyd, 1987 and Hull et al., 1980).

Based on the rather large variance among start-ups in the degree to which they have innovative versus imitative strategies (Samuelsson, 2001; Aldrich, 1999), one could argue that since many start-ups are imitative in nature, those should be excluded from the notion of entrepreneurship or at least viewed as a separate category. However, Davidsson (2003) formulates the argument for viewing imitative entry as 'new'. He notes that such entry drives the market process by giving consumers additional choices and challenging incumbent firms to change their behavior in response to new competition. In addition, he points out that no entrant is a perfect copy or 'clone' of an existing actor (Davidsson, 2003). In this sense, we use innovativeness not exclusively to refer to new products, but also to new markets and added value in the marketplace represented by the new firm.

\section{Franchise start-up}

A franchise start-up can be seen as an alternative to founding an independent firm (Kaufmann, 1999; Williams, 1998). Shane and Hoy (1996) refer to franchising as a form of cooperative entrepreneurship. Starting a franchise business can be considered less entrepreneurial than founding a firm from 'scratch' because it involves less innovation. Although a franchisee runs the risk of introducing the franchisor's concept into new markets, the potential for innovation is limited since maintenance of the franchisor's concept is important (Kaufman and Dant, 1998). Moreover, starting a franchise business also involves less opportunity perception and risk taking because the market concept has already been developed and tested, albeit not necessarily in the particular market where the entrepreneur is planning to start the franchise business.

tion", while the two highest correlated items within the third factor, "Organization Creation", mention opportunity recognition.

${ }^{7}$ Based on Kirchoff's (1994) Dynamic Capitalism Typology it can be argued that some innovations are successful and lead to growth and others are not. This indicates that even when innovation takes place, differences may exist in degree of entrepreneurship based on their contribution to firm growth. 


\section{Acquisition}

Purchasing an existing business was considered only a "slightly important" attribute in Gartner's study of expert definitions (Gartner, 1990). This may reflect a shift in the literature of the past few decades towards viewing entrepreneurship as creating market impact or societal value rather than as owning and running one's own firm. ${ }^{8}$ However, as a potential entrepreneurial activity, it is listed specifically in Vesper's Entrepreneurial Typology and has been included in various entrepreneurship research studies. Acquiring a business can be viewed as entrepreneurial since the purchase of an established business is preceded by opportunity perception. Although the acquirer is not involved in the founding of the business and the risk of start-up is circumvented, risk-taking is involved as the business is operated at the purchaser's own cost and risk. However, there may be relatively little need for innovation since the business is already established and resources have already been put to use. The extent to which the acquirer is innovative depends upon his or her plans to implement changes, and to pursue growth strategies, e.g., through entering new markets and/or developing new products (Cooper and Dunkelberg, 1986). On the other hand, the purchase may be inspired by an innovative idea the purchaser wants to implement to add value to the existing business. Because the purchaser of a business can develop and implement his/her own ideas, the acquisition of an established business may be more entrepreneurial than the purchase of a franchise where innovation tends to be more limited.

Acquisition may involve a healthy or a declining firm. When purchasing a declining firm with the intent of saving it, the acquirer faces even more challenges because the liabilities of the declining firm have to be translated or rendered into opportunities. On the other hand, a failing business can also be saved from within the firm, for instance by a manager, in which case risk takes on another form, not relating to a loss of ownership.

\section{Intrapreneurship / Corporate entrepreneurship}

Like business founders, intrapreneurs can be considered entrepreneurial because they introduce something new, albeit within a large business and its boundaries. Intrapreneurship differs from other forms of entrepreneurship with respect to the context in which the entrepreneurial act takes place. Like managers, intrapreneurs act on behalf of an existing organization instead of for their own account (Carrier, 1996). Because entrepreneurial ideas are implemented within the context of an existing organization, the ultimate risk is born by the owner of the

\footnotetext{
$\overline{{ }^{8} \text { Per Daviddson, personal communication, } 2003 .}$
} 
business instead of the initiator of the corporate venture. Risk is manifested by the probability of failure of the independent business unit and, accordingly, closure (Cunningham and Lischeron, 1991). In addition, an intrapreneur may risk the loss of his or her job or career disruption. Finally, alertness to opportunities is of similar importance for individual entrepreneurship and corporate entrepreneurship (Cunningham and Lischeron, 1991). Innovation within a firm does not necessarily take the form of creating a new business unit (i.e., intrapreneurship). It can also express itself in other ways, for instance, as adjustments to products and processes that do not require setting up a new unit. The innovator takes on other challenges than the intrapreneur, being more directly involved in the inventory and innovation process.

For the organization it is important to see and acknowledge the value of adopting new ways to organize and combine resources. Because innovation largely disrupts the existing organizational structure (i.e., rules, norms and procedures), there is a need for innovation champions, i.e., organization members who risk their own position to ensure the innovation's success (Schön, 1963; Burgelman, 1983; Shane, 1994). According to Howell and Higgins (1990) champions show higher risk-taking and innovativeness than non-champions within an organization. The degree of risk-taking and innovativeness is likely to be dependent upon the activities of the champion. Shane (1994) and Venkataraman et al. (1992) distinguish between different championing activities and roles 9 .

\section{Management of small vs. large firms}

It may be argued that there are differences in the degree of entrepreneurship between managers of different businesses. Someone managing a small business beyond the start-up phase faces different risks, i.e., challenges, as compared to someone managing a large business or someone managing a high-growth business. The different phases of the business involve different activities and different challenges, i.e., risks (Churchill and Lewis, 1983; Greiner, 1972; Garnsey, 1998). Based on the characteristics of opportunity perception, risk-taking and innovation one may propose that managers of small, young and high-growth firms are perceived as more entrepreneurial than those of established large firms.

\footnotetext{
${ }^{9}$ Shane (1994) argues that champions provide people with autonomy from organizational norms and rules; build coalitions to support the innovation with managers from different functional areas; build a decision-making mechanism that includes all organization members; use informal means to persuade people to support the innovation and protect the innovation teams from interference by the organizational hierarchy. Venkataraman et al. (1992) distinguish between different types of champions, including champions of ideas, resource champions, champions of opportunistic behavior and champions of incorporation.
} 


\section{Ownership vs. management}

Finally, several scholars have made a distinction between business owners and corporate managers (Carland and Carland, 1992; Smith et al., 1988). Owners are believed to show higher risk-taking than managers because their range of possibilities is larger and more uncertain (Bearse, 1982) and an owner has the ultimate responsibility for decisions (Gasse, 1982). Brandstätter (1997) argues that whether someone is seen as an entrepreneur is determined first by ownership, then by decision-making power and leadership functions and finally by the size of the company ${ }^{10}$. Hence, ownership is seen as more entrepreneurial than management, irrespective of firm size or characteristics.

\section{Tentative rankings based on the literature}

On the basis of the underlying entrepreneurial characteristics risk-taking, innovation and opportunity perception, we have made a first attempt to rank business accomplishments according to the degree of entrepreneurship involved. In addition to the business accomplishments previously mentioned, we include the category 'service provider' (e.g., accountant, banker, lawyer), as a sort of anchor, i.e., providing services to the business sector would least likely to be viewed as entrepreneurial, either by the general public or by entrepreneurship scholars. We also include family business as a type of business accomplishment, for exploratory reasons, even though there is little evidence in the literature to suggest that working in a family firm is more or less entrepreneurial than being involved in a non-family firm.

The results of the ranking are presented in Table 2. The ranking is done as follows. For three characteristics (opportunity perception, risk-taking and innovation) we discriminate between four levels (low, medium, medium-high, high). We assign the values 1 through 4 to these levels, respectively. The score of the business accomplishments equals the sum of these values. This leads to the ranking of business accomplishments as more or less entrepreneurial in Table 2. This ranking is based on our interpretation of the characteristics of the different entrepreneurial activities mentioned in the literature. On the basis of the previous discussion and Table 2 it can be argued that founding a firm from scratch involves the highest degree of entrepreneurship, followed by innovating behavior, intrapreneurship and managing a highgrowth business (tied to the third place), acquisition, starting a franchise business and managing a small business (tied to the fifth place), saving a failing business, supporting an innova-

\footnotetext{
${ }^{10}$ Based on a study of IMAS (Institut für Markt und Socialanalyzen), focusing on the perception of the Austrian population of what constitutes an entrepreneur in 1976 and 1986.
} 
tor, and, finally, managing a large business and providing services to an entrepreneur (tied to the tenth and last place).

Since ownership can involve a start-up, acquisition or franchise, it is difficult to determine the level of innovation involved. Accordingly, it is also difficult to rank the level of opportunity perception required. Hence, although ownership is included in the table, its ranking is left indeterminate. The ranking for family business is also left indeterminate as there is much variation between family businesses, their degree of entrepreneurship depending, for instance, upon the size and phase of the business and innovative capacity and ability.

Table 2 about here

\section{GENDER AND ENTREPRENEURSHIP}

In addition to business accomplishments, this paper explores the impact of gender on entrepreneurial self-image. This section summarizes past work on gender and entrepreneurship, including research on women in business, as well as research linking gender and selfperception in the business context.

\section{Women in Business}

Statistics regarding the participation of women in entrepreneurship have to be interpreted with caution. It has been argued that female start-up rates exceed those of men ${ }^{11}$. However, some of this increase is due to an overall increase of women in the labor market in most of the developed countries, including the United States. Despite the reported increase in female startup rates, women still constitute a minority of the total number of self-employed people, accounting for 25 to 35 percent of total business ownership in many Western countries (Carter, 2000) ${ }^{12}$. Reynolds et al. (2002) report that throughout the 37 countries participating in the Global Entrepreneurship Monitor men were 50 percent more likely to be involved in entrepreneurial activity than women ${ }^{13}$. Also in terms of proportion of the workforce, women constitute a minority. For instance, in the UK approximately 15 percent of the working male population

\footnotetext{
${ }^{11}$ See Center for Women's Business Research (www.womensbusinessresearch.org) and Carter (2000).

${ }^{12}$ For the United States, see US Small Business Administration (1995) and NFWBO (1996).

${ }^{13}$ In the Global Entrepreneurship Monitor entrepreneurial activity includes nascent entrepreneurs (starting or operating a business no older than three months) and new businesses (in existence for less than 3.5 years). See Reynolds et al., 2002, p. 38.
} 
is self-employed, versus about 9 percent of the working female population (Carter, 2000). Moreover, women-owned businesses underperform in a number of areas relative to menowned firms. Women-owned firms tend to engage in relatively underperforming sectors, such as retailing and services (U.S. Small Business Administration, 1995; OECD, 1998; Van Uxem and Bais, 1996), are smaller in size (Carter et al., 1997; Kalleberg and Leicht, 1991; Fischer et al., 1993; Verheul and Thurik, 2001), exhibit lower growth levels (Fischer et al., 1993; Hulshoff et al., 2001), have a higher rate of discontinuing, and lower profits (Carter et al., 1997).

Several reasons have been proposed to explain the performance differences between male and female-owned firms, including the level of relevant business experience (Cliff, 1998, Cromie and Birley, 1992; Watkins and Watkins, 1983; Kalleberg and Leicht, 1991; Fischer, et al., 1993; Verheul and Thurik, 2001), the proportion of total workweek committed to the business (Brush, 1992; Goffee and Scase, 1985; and Stigter, 1999), the propensity to take risks (Verheul and Thurik, 2001; Sexton and Bowman-Upton, 1990; Masters and Meier, 1988), age of the firm and the number of days a business operated (Watson, 2002), as well as the industry women are involved in (Watson, 2002; Verheul and Thurik, 2001). Others refer to differences in values across gender, positing that women value quality and other goals not directly related to growth and economic performance (Brush, 1992; Du Rietz and Henrekson, 2000; Kalleberg and Leicht, 1991; Rosa et al., 1996; Verheul and Thurik, 2001; Verheul et al., 2002).

Because the economic criteria of size and growth are often used as measures of success (Cliff, 1998; Buttner and Moore, 1997), and growth-orientation is considered an important entrepreneurial characteristic (Dunkelberg and Cooper, 1982), women may rate themselves as less entrepreneurial than men based on these objective differences, i.e., because they tend to manage small and low-growth businesses.

\section{Gender and Self-Perceptions in Business and Entrepreneurship}

Past research on gender differences in self-perception has mainly focused on managerial selfperception. In general, these studies indicate that women tend to underrate their skills or performance as compared to men (Wohlers and London, 1989; Lindeman et al., 1995). This underrating has been attributed to the fact that women often do not take credit for success, attributing success to external sources or luck rather than to effort or ability (Rosenthal et al., 1996; Parsons et al., 1982; LaNoue and Curtis, 1985). Moreover, Rosenthal et al. (1996) argue it may be 'proper female modesty' accounting for the underrating by female managers. 
Beyer (1990, 1998) and Beyer and Bowden (1997) argue that when (managerial) tasks and roles are perceived as more masculine than feminine, women are more likely than men to underestimate their competencies in these areas. Along these lines, several studies show that managers are perceived to have characteristics more commonly associated with men than with women (Schein, 1973 and 1975; Powell and Butterfield, 1979 and 1989). Within the area of entrepreneurship, Fagenson and Marcus (1991) find that women assign more weight to masculine attributes in the profile of a successful entrepreneur. A more recent study by Powell et al. (2002) finds that, although managerial stereotypes place less emphasis on masculine characteristics than earlier studies suggest, a good manager is still perceived to be predominantly masculine by both women and men. Hence, in spite of changes in the role of women in the US and internationally over the past several decades, we may still find entrepreneurship to be associated with masculine characteristics, such as autonomy, perseverance, high energy levels, self-confidence and decisiveness (Chaganti, 1986; Hisrich and Brush, 1983), likely to negatively affect the entrepreneurial self-image of women.

\section{MODEL AND HYPOTHESES}

We propose a model including the independent influence of both gender and business accomplishments on entrepreneurial self-image as well as the combined effect of gender and business accomplishments, i.e., the indirect effect of gender through accomplishments. The model is presented in Figure 1.

Figure 1 about here

Based on this model we test the following hypotheses. Hypothesis 1 represents the impact of certain business accomplishments on entrepreneurial self-image (arrow 2 in Figure 1). Hypothesis 1 is exploratory in nature as we make no a priori predictions about the effect of specific activities on entrepreneurial self-image, nor do we predict their respective weights. However, we would expect that those business accomplishments more clearly linked to entrepreneurship in the literature and/or more highly ranked by our panel of experts may have a higher influence on entrepreneurial self-image than those that are less highly ranked (See Tables 2 and 3$)$. 
Hypothesis 1: $\quad$ People with certain business accomplishments (e.g., the activities as proposed by Vesper $)^{14}$ will report a higher entrepreneurial self-image than those without such accomplishments.

We further argue that gender can have both a direct and an indirect effect on entrepreneurial self-image. The indirect effect refers to differences between men and women with respect to business accomplishments that lead, in turn, to differences in their entrepreneurial self-image (arrow 1 and 2 in Figure 1), whereas the direct effect refers to gender differences in self- image that can not be attributed to differences in business accomplishments (arrow 3 in Figure 1). The direct effect is the effect of gender on entrepreneurial self-image when controlling for the effects of business accomplishments. The model builds on previous research efforts distinguishing between direct and indirect gender effects in other areas of entrepreneurial behavior, such as financing (Verheul and Thurik, 2001).

As discussed earlier in the paper, women tend to underrate their skills or performance as compared to men. They often do not take credit for success and attribute it to external factors or luck. Moreover, when tasks and roles are perceived as more masculine than feminine, women are more likely to underestimate their competencies in these areas. Irrespective of how it is measured, entrepreneurship is often perceived of as more masculine than feminine, so that women may be expected to perceive of themselves less as entrepreneurs. However, past research also shows that women are less likely to own and run a business than men. Moreover, as they tend to focus on quality (Chaganti and Parasuraman, 1996; Brush, 1992), women are expected to be involved less often in managing a high-growth or large business. This leads to the formulation of Hypothesis 2a, representing the direct effect of gender on entrepreneurial self-perception (see arrow 3 in Figure 1) and Hypothesis 2b, predicting an indirect effect of gender on entrepreneurial self-image (see arrow 1 and 2 combined in Figure 1), with business accomplishments posited as (partially) mediating that effect. To summarize, we can state Hypotheses $2 \mathrm{a}$ and $2 \mathrm{~b}$ as follows:

Hypothesis 2a: Women have a lower entrepreneurial self-image than men, controlling for their particular business accomplishments (the direct effect).

Hypothesis 2b: Women have a lower entrepreneurial self-image than men due to differences in particular business accomplishments (the indirect effect). That

\footnotetext{
${ }^{14}$ In addition to the entrepreneurial activities of Vesper's typology in Table 1, in the empirical analysis we include additional activities (i.e., Owner, Service Provider and Family Business) to create a better insight into the influence of activity on entrepreneurial self-perception (see Table 3).
} 
is, business accomplishments partially mediate the relationship between gender and entrepreneurial self-image.

\section{RANKING ENTREPRENEURIAL BEHAVIORS ACCORDING TO AN EXPERT PANEL}

\section{Method}

To validate the earlier proposed (literature) ranking of business accomplishments we make use of an expert panel, including 216 respondents, each of whom were asked to give their opinion about the same list of business accomplishments used in the rest of the study (see Appendix $)^{15}$. In particular, respondents were asked to indicate the extent to which each of these activities is an example of entrepreneurship or entrepreneurial behavior according to the following scale: (1) definitely; (2) probably; (3) maybe; (4) don't think so; (5) no; and (6) don't know $^{16}$. Respondents were considered 'experts', and were included in the study, if they had been working either as an academic or practitioner in the field of entrepreneurship for at least one year ${ }^{17}$. Of the 216 respondents, 162 were included as experts in the study ${ }^{18}$.

\section{Results of the Expert Panel Study}

Expert panel scores for each of the activities are displayed in Table 3. The ranking of the activities according to the experts appears fairly similar to the ranking based on the literature. Starting a business from scratch (i.e., Founder) is considered, by far, most entrepreneurial, followed by Intrapreneur, someone doing new things not involving a business (unit) (i.e., Innovator), managing a high-growth business (i.e., Take-Off Artist), starting a franchise business (i.e., Franchisee) and running a small business beyond start-up (i.e., Runner). The only rank-

\footnotetext{
${ }^{15}$ Questionnaires were distributed to international experts on six different occasions: (1) Research in Entrepreneurship and Government Policy (Vlerick Leuven Gent Management School), Leuven, 27 August 2002 (29 respondents), (2) the $29^{\text {th }}$ International Small Business Congress (RAI International Congress and Exhibition Centre), Amsterdam, 27-30 October 2002 (33 respondents), (3) the opening of the Rotterdam Incubation Centre Area010 (World Trade Centre Rotterdam), 5 November 2002 (43 respondents), (4) the $25^{\text {th }}$ ISBA National Small Firms Policy and Research Conference (Brighton Business School), Brighton 13-15 November 2002 (25 respondents), (5) the RENT XVI (Research in Entrepreneurship and Small Business) Conference (Universitat Autonoma de Barcelona), Barcelona, 21-22 November 2002 (64 respondents) and (6) the UKBI $4^{\text {th }}$ National Incubation Conference, Edinburgh, 25-26 November 2002 (22 respondents).

${ }^{16}$ The answer: (6) "don't know" was coded missing.

${ }^{17}$ Practitioners include the following: government officials or policy makers, consultants or service providers (e.g., bankers, accountants, or lawyers). Academics include researchers and/or instructors at the university level, excluding students. In an additional analysis, academics and practitioners were separated into two subsamples but the rank orderings remained essentially the same. Hence, the combined means are reported here.
} 
ing that is out of order, when comparing our proposed ranking (in Table 2) and that of the expert panel, is that of Acquirer (which in the expert panel has a ranking of ' 8 ' as compared with a tie for 7 th place based on the literature review).

In reviewing the distribution of responses, about 10 percent of the respondents consider Service Provider an entrepreneur, and Family Business receives a higher rating than Champion, Owner, or Industry Captain, which have been variously argued in the literature as having entrepreneurial elements. All of the business accomplishment items were given a rating of either ' 1 ' or '2' (indicating that a respondent considers the behavior either 'definitely' or 'probably' to be an example of entrepreneurial behavior) by at least 19 percent of the respondents in the expert panel. Based on these results, we decided to include all business accomplishments in further exploratory analyses based on the alumni panel dataset, even though some have a relatively low rating.

Table 3 about here

\section{TESTING THE PROPOSED MODEL AND HYPOTHESES}

\section{Method}

Data source and sample characteristics

To test the relationships between gender, business accomplishments and entrepreneurial selfperception, about 2000 questionnaires were sent to various subsamples of alumni at a large Midwestern public university in the United States: 512 to MBA graduates (72 or 14\% of which responded); 1200 to alumni identified as either a president or CEO in the Dun and Bradstreet database (118 or $10 \%$ of which responded); and 283 to recent graduates who had enrolled in an entrepreneurship course while at college (17 or $9 \%$ of which responded). Of these questionnaires 331 were returned to sender, and 212 responded, of which five were unusable due to incomplete information. The sample is non-random but still useful from an exploratory standpoint. Of the total sample, 148 were male and 59 were female.

Sample selection was hampered by the fact that in spite of the university's age (about 150

\footnotetext{
${ }^{18}$ The distribution of the 162 respondents is as follows: 18 (Area010 in WTC, Rotterdam), 23 (Vlerick Leuven Gent Management School, Leuven), 28 (ISBC, Amsterdam), 56 (RENT XVI, Barcelona), 21 (ISBA, Brighton)
} 
years old), as with many public universities of its type, the university kept incomplete information of its alumni. It had only recently set up an alumni office to track graduates. Selected sub-samples were chosen to increase the likelihood that alumni would indeed be business founders and owners. The research team sent a cover letter, with an enclosed stamped return envelope, explaining that the Business Faculty of the university was interested in gathering additional information about the activities of its alumni. Although alumni were asked to complete the questionnaire regardless of whether or not they are a business owner, the letter also indicated that the purpose of the project was indeed to identify alumni who had either started or run their own companies and also to identify alumni who might be eligible for recognition for their entrepreneurial achievements by the university.

The relatively low response rate for the overall population may be explained by several factors. First, due to the specific topic of the survey, and especially since few questionnaires were returned incomplete, there is the likelihood of a self-selection bias where only those responded who were actually involved in the entrepreneurship or business activities as indicated in the questionnaire ${ }^{19}$. In hindsight, the content of the cover letter - which was constructed not only for research but also non-research purposes - as well as the content of the survey itself a two-page survey, which in addition to background questions (name, address, educational history, gender and age) was primarily aimed at identifying business accomplishments likely skewed the response rate toward those individuals who already perceived themselves as entrepreneurs. Nevertheless, the responses, especially concerning the dependent variable, were of sufficient range (with a standard deviation of 1.57) to warrant further analysis (see Table 5).

The low response rate may be further explained by the fact that letters were sent out to company addresses instead of to individuals and it was a one-time mailing with no announcement or follow-up. Finally, the relatively low response rate, especially for the sub-sample of recent graduates, may be attributed to the mobility of recent graduates, resulting in letters arriving at the wrong address.

The sample mainly consists of high-educated individuals, probably resulting in an education bias. Approximately 50 percent of the respondents hold a Masters degree, and 43 percent hold

and 16 (UKBI, Edinburgh).

${ }^{19}$ This is supported by the fact that about 60 percent of the respondents reported having founded their own firms, which is higher than expected in the general population. For instance, Delmar and Davidsson (2000), referring to a US sample from Reynolds (1997), indicate that 37.5 percent of the US respondents reported to be involved in any start-up or small business experience. The actual percentage of people having founded a business in this sample is likely to be even smaller. 
a Bachelors diploma. Of the people with a university degree (either Bachelors or Masters) approximately 60 percent reported having specialized in business.

Finally, when compared to other available entrepreneurship data, it seems that our sample is characterized by a relatively high average age. While in our study the average age is 50 years, Evans and Leighton (1989a) report an average age of an entrepreneur of 40 years. Moreover, Storey (1994) reports that people typically start a business between 25 and 40 years old. This is confirmed by Reynolds et al. (1999) arguing that countries with more individuals in the age class of 25 to 44 years, are characterized by higher start-up rates ${ }^{20}$. However, in our study, most of the respondents (approximately 50 percent) fall in the age category of 46 to 55 years old (see Table 5). This relatively high age of the respondents in the sample may be related to the self-selection bias alluded to earlier. That is, because respondents were asked to indicate their business accomplishments (see Appendix), this may have influenced the age distribution in the sample since younger people would be less likely to have accomplishments to report, and, accordingly, be more hesitant to fill in and return the survey. In summary, given the nonrandomness of the sample, and the response bias regarding age, education and location, conclusions drawn from this study should be viewed as exploratory in nature.

\section{Description of Variables}

The Appendix to the present paper summarizes the way in which dependent, independent and control variables are measured.

\section{Business accomplishments}

The classification of business accomplishments is based on the entrepreneurial typology as proposed by Vesper (1999). See Table 1. The following business accomplishments: Founder, Acquirer, Runner, Take-Off Artist, Turnaround Artist, Intrapreneur, Innovator, Industry Captain and Champion, are drawn directly from Vesper's Entrepreneurial Typology. Three additional business accomplishments (i.e., Owner, Service Provider and Family Business) are included in the analysis to create more insight into the impact of the different business accomplishments on Entrepreneurial Self-Image. We also added the distinction between starting a new business from scratch (i.e., Founder) versus starting a franchise business (i.e., Franchisee).

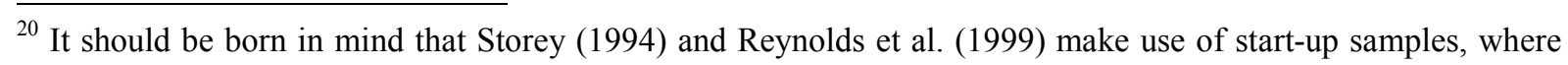
individuals are likely to be younger.
} 


\section{Gender}

Gender was measured using a single self-report item on the questionnaire.

\section{Control variables}

According to human capital theorists (see Becker, 1964) knowledge increases the cognitive ability of an individual, resulting in more efficient and effective behavior. Davidsson and Honig (2003) suggest that individuals with higher levels of human capital are more selfconfident. Although human capital has been studied in the context of entrepreneurial behavior and success (Evans and Leighton, 1989b; Bellu et al., 1990; Bates, 1995; Gimeno et al., 1997; Manolova et al., 2002), it has not been investigated in the context of (entrepreneurial) selfperception. People with higher levels of human capital may be expected to have a more developed self-perception, being aware of their own capabilities. A distinction can be made between different types of knowledge - tacit versus explicit (Polyani, 1966) - and, accordingly, between different types of learning or education. Davidsson and Honig (2003) refer to formal (e.g., university education), informal (e.g., work experience) and non-formal education (e.g., specific training).

In the present study we include the following human capital factors: education level, business degree (whether at the bachelors or masters level), and introduction course (i.e., whether or not the respondent had taken an introductory course in entrepreneurship while at the university). In addition, we include age of the respondent as a control variable. Since experience tends to increase with age, we want to separate these two effects.

\section{Data Analysis}

In an effort to reduce the number of business accomplishment items to meaningful scales, we first perform a factor analysis with the alumni dataset, using Principal Components Analysis and a Varimax rotated solution to identify independent factors.

The relationship between business accomplishments and entrepreneurial self-image, represented by Hypothesis 1 (arrow 2 in Figure 1), is tested with Pearson product-moment correlation coefficients and is investigated in the regression analyses. Hypothesis 2a (representing the direct gender effect) and Hypothesis $2 b$ (representing the indirect gender effect) are tested through a series of linear regressions introducing the explanatory variables (gender, business accomplishments and controls) in blocks, comparing their respective contributions.

One can test for the mediating effect of variable, $m$ (=business accomplishments), by demon- 
strating that the relation between proposed antecedent, $x$ (=gender), and consequence, $y$ (=self-image), vanishes if $m$ is included in the model (James and Brett, 1984). There are two accepted protocols proposed in the literature for testing for mediating effects. In either approach, one must test first that the relationships between $x$ and $y, x$ and $m$, and $m$ and $y$ are all significant in bivariate tests of correlation. In the next step, according to the James and Brett (1984), first testing the model $y=\mathrm{f}(m)$ and then the model $y=\mathrm{f}(m, x), m$ can be seen as completely mediating the relationship between $x$ and $y$ if the added effect of $x$ (tested by the significance of the $R$-squared change when $x$ is added last) should be not significant in the linear regression. A second approach, outlined by Baron and Kenny (1986), and used, for instance by Nerkar, McGrath and MacMillan (1996), proposes to compare the results of Model 1, where $y=\mathrm{f}(x)$, with those of Model 2, where $y=\mathrm{f}(x, m)$. In this latter method, to support the inference that $m$ completely mediates the effect of $x$ on $y$, the unstandardized coefficient $B_{x}$ should be significant in Model 1 but not significant in Model 2. Further, the unstandardized coefficient $B_{m}$ in Model 2 should be significant. Both protocols are reported and compared in the current study (see Table 6).

Throughout the paper we worked with both one- and two-tailed hypotheses. As critical values of the one-tailed test procedures always exceed that of the two-tailed test procedures, we leave out the one-tailed results for ease of presentation. Also, the present study is exploratory in nature, and although we hypothesize a particular direction in some cases, we do not rule out the possibility that effects can be in either direction.

\section{RESULTS}

\section{Factor Analysis and Scale Formation for Business Accomplishments}

Table 4 presents a seven-factor solution for the different business accomplishment items included in the questionnaire. Although the Eigenvalues for factors 6 and 7 are relatively low ( 0.92 and 0.79 , respectively), seven factors are specified to have a better view of the independence of several of the business accomplishments, providing support for the decision to separately include these accomplishments in further analyses. Including the most important items (with factor loadings $\geq 0.60$ ), Cronbach's Alpha amounts to 0.64, 0.52 and 0.51 for factors 1, 2 and 3, respectively. Although these reliabilities are not particularly high, Factors 1 and 2, in particular, appear fairly reasonable to interpret on the basis of their content. Factors 4 to 7 are made up of one item only. Although Acquirer and Turnaround Artist load on the same 
factor (Factor 3), they are included separately in the analyses because of a low face validity for the factor: acquiring a business does not necessarily imply that the purchased firm is in distress and needs to be 'saved'. Also, someone saving a failing business is not necessarily a business owner, but can be a manager.

Table 4 here

Eight business accomplishment variables are identified for further analyses: Small Business Person (consisting of Founder, Runner and Owner), 'Corporate' Entrepreneur (consisting of Intrapreneur, Innovator and Champion), Acquirer, Turnaround Artist, Franchisee, Industry Captain, Service Provider, and Family Business. The business accomplishment, Take-Off Art$i s t$, is omitted from further analyses because it did not clearly load on any of the seven factors specified.

\section{Descriptive and Bivariate Statistics}

Table 5 reports the means, standard deviations, and correlation coefficients between the major variables in this study.

Table 5 about here

\section{Test for H1: Relationships between Business Accomplishments and Entrepreneurial}

\section{Self-Image}

$\mathrm{H} 1$ is tested first by examining the relationships between each of the business accomplishments and Entrepreneurial Self-Image. Though no predictions are made a priori, reviewing the bivariate correlation statistics presented in Table 5 provides support for the relationship between Entrepreneurial Self-Image and three of the business accomplishment variables, including Small Business Person ( $r=0.56, p<0.01)$, Acquirer $(r=0.16, p<0.05)$, and Industry Captain $(r=0.16, p<0.05)$.

Table 6 presents the results of three models, all predicting Entrepreneurial Self-Image: Model 1 includes the effects of Business Accomplishments and control variables (Age, Education Level, Business Degree and Introductory Course). Model 2 reports the effects of Gender and 
the control variables. Finally, Model 3, the all variable model, includes effects for all three sets of variables (Business Accomplishments, controls and Gender). In addition, the last column in Table 6 reports the change in $R^{2}$ for two separate analyses (either when a block is entered first or last in the all variable regression model). As indicated in the last column, the $R^{2}$ for Business Accomplishments alone is $0.32(p<0.01)$. The significance levels of the $B$-values are similar whether or not the control variables are taken into account.

When entered first in the analysis as a block of variables, Business Accomplishments explain about 32 percent of the total variation. The majority of the variance $\left(R^{2}\right)$ is explained by the Small Business Person scale, followed by Turnaround Artist activity (albeit opposite to the predicted direction). In sum, these results imply support for Hypothesis 1.

Table 6 here

\section{Test for H2: Gender effects on Entrepreneurial Self-Image controlled for Business Ac- complishments}

As shown in Table 5, the bivariate relationship between Gender and Entrepreneurial SelfImage is significant and negative $(r=-0.23 ; p<0.01)$, suggesting a significant total gender effect. As shown in Model 3 of Table 6, the unstandardized coefficient for Gender is significant $(B=-0.67, p<0.01)$, even when the effects of Business Accomplishments and the selected human capital variables are controlled for in the linear regression model. Both results support the inference that Gender has a direct effect on Entrepreneurial Self-Image (see Hypothesis 2a) and there is a partial mediating effect of Business Accomplishments (and the control variables), albeit relatively weak - reducing at best, the adjusted $R^{2}$ by two percentage points, from 0.05 to 0.03 . Because the adjusted $R^{2}$ for Gender does decrease somewhat, there is weak support for the inference that Business Accomplishments may partially mediate the relationship between Gender and Entrepreneurial Self-Image (see Hypothesis $2 b)^{21}$.

In addition to Business Accomplishments and Gender, Education Level and Business Degree influence Entrepreneurial Self-Image. Interestingly, they both negatively influence Entrepreneurial Self-Image. Hence, the higher the level of education an individual attained, the lower the individual's entrepreneurial self-perception. In addition, the type of education seems to 
influence Entrepreneurial Self-Image, with people having a business degree being less likely to perceive of themselves as entrepreneurs. However, there does not appear to be either an effect of Age on Entrepreneurial Self-Image.

\section{DISCUSSION}

\section{Further Discussion of Results}

To further our understanding of the popular view of the concept of "entrepreneur," the research objective of this paper sets out to answer the following question: "Do certain characteristics of individuals influence their entrepreneurial self-image, i.e. the extent to which they perceive themselves to be entrepreneurs?" The primary set of characteristics, the respondent's business accomplishments, is derived from a typology of entrepreneurial activities proposed by Vesper (Vesper, 1999).

Some interesting patterns emerge in our exploratory study: Entrepreneurial Self-Image is influenced by certain business accomplishments defined in the literature as being entrepreneurial. This is consistent with self-perception theory (Bem, 1972). Business owners, founders, and small to mid-sized business managers (combined in this study's Small Business Person scale) are most likely to describe themselves as entrepreneurs. On the other hand, Corporate Entrepreneurs (including intrapreneurs, innovators, and champions) are not likely to call themselves entrepreneurs.

The negative contribution of Turnaround Artist activity on Entrepreneurial Self-Image in the regression analyses, reported in Table 6, must be carefully interpreted. It is included in the analysis even though it is fairly strongly correlated with the Acquirer variable $(r=0.36$, $p<0.01)$ and both load on the same factor in the seven-factor solution derived from the factor analysis. Furthermore, although the $t$-value for Turnaround Artist is statistically significant in the regression analysis, note that the zero-order correlation coefficient is practically zero. One explanation for this may be that because both items are included in the regression equation, the common effect is controlled for (i.e., Turnaround Artists who are also Acquirers). Thus, the residual effect of Turnaround Artist may represent in particular the (non-owner)/manager in a larger firm who comes in to professionalize the firm and, accordingly, views him- or herself as the antithesis of the entrepreneur.

\footnotetext{
${ }^{21}$ In a separate regression analysis, we also tested specifically for interaction effects of each business accomplishment and gender. However, we did not find evidence of interaction effects.
} 
Another major thrust in this study is the examination of gender effects on Entrepreneurial Self-Image. Although small in absolute terms, the regression analyses do provide partial evidence that Gender affects Entrepreneurial Self-Image indirectly by way of the business accomplishments of those individuals. Regression analyses provide more convincing evidence of a direct effect of Gender on Entrepreneurial Self-Image, i.e., Entrepreneurial Self-Image is influenced directly by Gender, independently of the Business Accomplishments reported by respondents.

In addition to the effects of Business Accomplishments and Gender, the regression results reveal significant effects of certain human capital variables in the prediction of Entrepreneurial Self-Image, although in a somewhat unexpected direction. Both the level of education and possession of a business degree contribute negatively to Entrepreneurial Self-Image, even after controlling for the effect of Small Business Person activity. This seems a counterintuitive finding as it would be expected that knowledge (whether general or specific) positively contributes to the self-awareness of individuals. It may be that the negative effect of Education Level is related to the fact that more highly educated people tend to want to work for large companies, where business size is an important prestige factor. Or maybe the term "entrepreneur" connotes small business and/or lower professionalism among respondents, depending upon the way in which the term has been applied when these alumni attended the university.

Though it is true that the surveys for the expert panel and alumni panel were set up differently, it is interesting that there is a significant divergence of opinion - depending on one's interpretation of the results - in what is entrepreneurial according to the experts and which business accomplishments create an identity as an entrepreneur among the general business community. For instance, the Corporate Entrepreneur scale does not contribute to Entrepreneurial Self-Image, even though the Intrapreneur and Innovator items, in particular, are ranked highly in the expert panel study. Future research may want to explore more specifically the relationship between the perceptions of the scholarly community and the general business community regarding their definitions of entrepreneurship ${ }^{22}$.

\footnotetext{
${ }^{22}$ It is possible that there is a lagged effect, in that the meaning of the term, as given by scholars, influences the general business community and/or society-at-large, but with a time lag so that we can begin to expect notions, such as corporate entrepreneurship, to enter the community's vocabulary in increasing frequency, based on its usage in scholarly circles. But then, we are acknowledging that scholars are constructing the concept of entrepreneurship, consistent with the social constructionist view of reality rather than merely observing that reality and measuring it (see Healy and Perry, 2000).
} 


\section{Directions for Future Research}

This study provides a starting point for other (follow-up) studies investigating and explaining entrepreneurial self-perception. The exploratory nature of this study requires that we share our views on its limitations with the reader. We have also made suggestions for future research that would help to remedy these limitations and to further build on our findings.

The present study uses a non-random sample to test the hypotheses. Furthermore, there is selfselection among respondents, suggesting that a large portion of those not viewing themselves as entrepreneurs chose not to return their surveys. Within the sample (college graduate level and above) we see that education level has a negative effect on Entrepreneurial Self-Image. However, there may be a threshold level of education, below which education may positively influence self-perceptions (through increased self-awareness). Also, the average age in our sample is relatively high, i.e., 50 years. It may be that the specific age distribution in the sample has influenced the degree to which people see themselves as entrepreneurs. For instance, older people may be less likely to perceive of themselves as entrepreneurs, because at the start of their activities entrepreneurship was not considered an important career option, and was less accepted than it is at present. Hence, further research on entrepreneurial self-perception needs to include random sampling to represent different educational backgrounds and age to control for such spurious effects more accurately. Hence, the results should be interpreted with caution.

The operationalization of the variables in this study are fairly simply conceived. The dependent variable entrepreneurial self-image is based on a single item. Also, the original scale measuring entrepreneurial self-perception should be further improved, including 'possibly' instead of 'probably'.

Future research can also benefit from measurement of intervening variables, such as perceived risk-taking, creativity and innovation, to explain the linkages found between business accomplishments and entrepreneurial self-perception. This may occur either through direct measurement of these concepts or through a more detailed exploration of the various activities regarding, for example, the uniqueness of the company started or the changes made once a company is acquired.

Based on the methodology used in the present study, which compares current self-perceptions on present as well as past behavior, it may be argued that the causality between business accomplishments and self-perception can be in either direction. However, due to the design of 
the study, business accomplishments had to have taken place prior to completion of the questionnaire. Therefore, it is plausible to assume that at least in part, these business accomplishments were the cause of the particular level of entrepreneurial self-image rather than the reverse. However, future research using a longitudinal design would need to take place to establish the direction of the causality more firmly.

The culture-dependency of the self-concept may limit the extent to which the results of the present study, using American data, can be translated to countries or regions outside the United States ${ }^{23}$. Hence, future research should also compare entrepreneurial self-perceptions in different cultural settings as a specific aspect of the broader concept of self-concept.

In summary, in spite of limitations due to the small, non-random sample, results from this study point toward fruitful directions for future research on entrepreneurial self-perception. In particular, more representative samples of the general public, including those with lower education and with a more representative age and education, as well as larger samples from different cultures may provide the basis for generalization of results. In addition, the introduction of a more fully developed list of business accomplishments (e.g., innovative versus noninnovative start-ups), the use of a longitudinal design to test for the direction of causality), and direct tests of intervening variables may better able to explain the linkages found in this study between both business accomplishments and gender with the dependent variable.

\section{Practical Implications}

At a more practical level, if gender differences in entrepreneurial self-perception hold in follow-up research, different guidelines for attracting, supporting and counseling female entrepreneurs and small business owners should be considered by directors of small business service centers and other service providers. Referring to the direct gender effect, it may be that the term "entrepreneurship" does not appeal to women, i.e., that they cannot identify with the term, and accordingly, the use of the word "entrepreneurship" may lead to self-selection. The lack of relevance of the term "entrepreneurship" for women has important implications for the marketing of the concept, both in the education system (e.g., university) and in the market. At the university level the use of the term "entrepreneurship" may 'turn off' women in the area of entrepreneurship conferences, student clubs, courses, majors and career services ${ }^{24}$. Also out-

\footnotetext{
${ }^{23}$ Evidence of cultural differences regarding the self-concept is presented by Abe et al. (1996) distinguishing between independent and interdependent cultures. See also Markus and Kitayama (1991) and Triandis (1989).

${ }^{24}$ As a faculty advisor at a Midwestern U.S. university one of the authors reports that after changing the name of the university student club from Entrepreneur's Club to Future Business Owners Club, female students attended meetings in much higher numbers.
} 
side the university one should be cautious using the term "entrepreneurship", for instance in government support programs and within other agencies providing services to entrepreneurs to avoid the same result. In sum, dealing with or targeting women organizations should pay attention to the negative connotation the term "entrepreneurship" may have and, where possible, supplement or clarify it.

\section{CONCLUSION AND SUMMARY}

The main goal of this study is to shed light on the various interrelationships between business accomplishments, gender, and entrepreneurial self-perception. The findings, taken together, clearly support the explanatory power of Business Accomplishments to predict Entrepreneurial Self-Image, in line with Bem's self-perception theory. In particular, the greater part of the variation in Entrepreneurial Self-Image can be explained by the business activities in which respondents participate. Gender, though weaker in its explanatory power, also appears to provide added explanation to the model, most clearly as a separate direct effect on Entrepreneurial Self-Image, but with a likely indirect effect (through Business Accomplishments) as well. In particular, we find that women tend to select different activities than men, choosing less frequently those activities both genders view as entrepreneurial. In addition, women are less likely to perceive of themselves as entrepreneurs, independently of activities undertaken. It may be that women also value the same business accomplishments differently than men do, although the present study cannot determine the extent of this third gender effect.

In sum, although some of the gender effects are small in absolute terms, the study does demonstrate the importance of including gender as an explanatory variable in general research questions of interest in the field of entrepreneurship. Finally, at a more practical level, if these differences hold up in follow-up research, different guidelines for attracting, supporting and counseling female entrepreneurs and small business owners should be considered by directors of small business service centers and other service providers. Further research is needed to provide direction for such guidelines.

\section{REFERENCE LIST}

Abe, S., Bagozzi, R.P. and P. Sadarangani, 1996, An investigation of construct validity and generalizability of the self-concept: self-consciousness in Japan and the United States, Journal of International Consumer Marketing 8 (3,4), 97-123.

Aldrich, H., 1999, Organizations Evolving, Newbury Park, CA: Sage Publications. 
Bandura, A., 1977, Self-efficacy: Toward a unifying theory of behavioral change, Psychological Review 84, 91-215.

Bandura, A., 1986, Social Foundations of Thought and Action: A Social Cognitive Theory, Englewood Cliffs, NJ: Prentice-Hall.

Baron, R.M., and D.A. Kenny, 1986, The moderator-mediator variable distinction in social psychological research: Conceptual, strategic, and statistical considerations, Journal of Personality and Social Psychology, 51 (6), 1173-1182.

Bates, T., 1995, Self-employment entry across industry groups, Journal of Business Venturing 10 (2), 143-156.

Bearse, P.J., 1982, A study of entrepreneurship by region and SMSA size. In: Vesper, K.H. (ed.), Frontiers of Entrepreneurship Research, Wellesley, MA: Babson College, 78-112.

Becker, G.S., 1964, Human Capital, Chicago: The University of Chicago Press.

Begley, T.M., 1995, Using founder status, age of firm, and company growth rate as the basis for distinguishing entrepreneurs from managers of smaller businesses, Journal of Business Venturing 10 (3), 249-263.

Begley, T.M. and D.P. Boyd, 1987, Psychological characteristics associated with performance in entrepreneurial firms and smaller businesses, Journal of Business Venturing 2, 79-93.

Bellu, R., Davidsson, P. and C. Goldfarb, 1990, Toward a theory of entrepreneurial behavior: Empirical evidence from Israel, Italy and Sweden, Entrepreneurship and Regional Development 2 (2), 195-209.

Bem, D.J., 1972, Self-perception theory. In: Berkowitz, L. (ed.), Advances in Experimental Social Psychology 6, 1-62.

Beyer, S., 1998, Gender differences in self-perception and negative recall biases, Sex Roles 38, 103133.

Beyer, S., 1990, Gender differences in the accuracy of self-evaluations of performance, Journal of Personality and Social Psychology 54, 5-12.

Beyer, S. and E.M. Bowden, 1997, Gender differences in self-perceptions: convergent evidence from three measures of accuracy and bias, Personality and Social Psychology Bulletin 23, 157-172.

Boyd, N.G. and G.S. Vozikis, 1994, The influence of self-efficacy on the development of entrepreneurial intentions and actions, Entrepreneurship Theory and Practice 18 (4), 63-77.

Brandstätter, H., 1997, Becoming an entrepreneur - a question of personality structure? Journal of Economic Psychology 18, 157-177.

Brockhaus, R.H., 1980, Risk taking propensity of entrepreneurs, Academy of Management Journal 23 (3), 509-520.

Brockhaus, R.H. and W.R. Nord, 1979, An exploration of factors affecting the entrepreneurial decision: personal characteristics versus environmental calculations, Academy of Management Proceedings, 364-368.

Brockhaus, R.H. and P. Horwitz, 1986, The psychology of the entrepreneur. In: Sexton, D.L. and R.W. Smilor (eds.), The Art and Science of Entrepreneurship, Cambridge, Mass: Ballinger Publishing Company, 25-60.

Brush, C.G., 1992, Research on women business owners: past trends, a new perspective and future directions, Entrepreneurship: Theory and Practice 16 (4), 5-30.

Burgelman, R.A., 1983, A process model of internal corporate venturing in the diversified major firm, Administrative Science Quarterly 28 (2), 223-244.

Cantillon, R., 1931, Essai sur la Nature du Commerce en Général, edited and translated by H. Higgs, London: MacMillan.

Carland, J.W. and J.A. Carland, 1992, Managers, small business owners and entrepreneurs: the cognitive dimension, Journal of Business and Entrepreneurship 4 (2), 55-62.

Carland, J.W., Hoy, F., Boulton, W.R. and J.C. Carland, 1984, Differentiating entrepreneurs from small business owners: a conceptualization, Academy of Management Review 9 (2), 354-359. 
Carrier, C., 1996, Intrapreneurship in small businesses: an exploratory study, Entrepreneurship Theory and Practice 21 (1), 5-20.

Carter, S., 2000, Gender and Enterprise. In: Carter, S. and D. Jones-Evans (eds.), Enterprise and Small Business. Principles, Practice and Policy, Harlow: Prentice Hall / Pearson Education Limited.

Carter, N.M., Williams, M. and P.D. Reynolds, 1997, Discontinuance among new firms in retail: the influence of initial resources, strategy and gender, Journal of Business Venturing 12 (2), 125-145.

Chaganti, R., 1986, Management in women-owned enterprises, Journal of Small Business Management 24 (4), 18-29.

Chandler, A., 1990, Scale and Scope: The Dynamics of Industrial Capitalism, Cambridge, Mass: Harvard University Press.

Chen, C.C., Greene, P.G. and A. Crick, 1998, Does entrepreneurial self-efficacy distinguish entrepreneurs from managers? Journal of Business Venturing 13 (4), 295-316.

Churchill, N.C. and V.L. Lewis, 1983, The five stages of small firm growth, Harvard Business Review May-June, 30-50.

Cliff, J.E., 1998, Does one size fit all? Exploring the relationship between attitudes towards growth, gender and business size, Journal of Business Venturing 13, 523-542.

Cooper, A.C. and W.C. Dunkelberg, 1986, Entrepreneurship and paths to business ownership, Strategic Management Journal 7, 53-68.

Cromie, S. and S. Birley, 1992, Networking by female business owners in Northern Ireland, Journal of Business Venturing 7 (3), 237-251.

Cunningham, J.B. and J. Lischeron, 1991, Defining entrepreneurship, Journal of Small Business Management 29 (1), 45-61.

Damrad-Frye, R. and J.D. Laird, 1989, The experience of boredom: The role of the self-perception of attention, Journal of Personality and Social Psychology 57 (2), 315-320.

Davidsson, P., 2003, The domain of entrepreneurship research: some suggestions, in: J. Katz and D. Shepeard (eds.), Advances in Entrepreneurship; Firm Emergence, and Growth, volume 6, Greenwich, CT: JAI Press.

Davidsson, P. and B. Honig, 2003, The role of social and human capital among nascent entrepreneurs, Journal of Business Venturing 18 (3), 301-331.

Delmar, F. and P. Davidsson, 2000, Where do they come from? Prevalence and characteristics of nascent entrepreneurs, Entrepreneurship and Regional Development 12 (1), 1-23.

Dolinski, D., 2000, On inferring one's beliefs from one's attempt and consequences for subsequent compliance, Journal of Personality and Social Psychology, 78 (2), 260-272.

Du Rietz, A. and M. Henrekson, 2000, Testing the female underperformance hypothesis, Small Business Economics 14, 1-10.

Dunkelberg, W.C. and A.C. Cooper, 1982, Entrepreneurial typologies: an empirical study. In: Vesper, K.H. (ed.), Frontiers of Entrepreneurship Research, Wellesley, MA: Babson College, 1-15.

Evans, D.S. and L.S. Leighton, 1989a, The determinants of changes in US self-employment, 19681987, Small Business Economics 1 (2), 111-119.

Evans, D.S. and L.S. Leighton, 1989b, Some empirical aspects of entrepreneurship, American Economic Review 79 (3), 519-535.

Fagenson, E.A. and E.C. Marcus, 1991, Perceptions of the sex-role stereotypic characteristics of entrepreneurs: women's evaluations, Entrepreneurship: Theory and Practice 15 (4), 33-47.

Forehand, M.R., 1998, An inferential priming model of promotional response, Dissertation Abstracts, International Section A: Humanities and Social Sciences 58 (9-A), 3619.

Fischer, E.M., Reuber, A.R. and L.S. Dyke, 1993, A theoretical overview and extension of research on sex, gender and entrepreneurship, Journal of Business Venturing 8, 151-168.

Garnsey, E., 1998, A theory of early growth of the firm, Industrial and Corporate Change 7, 523-556.

Gartner, W.B., 1989, "Who is an entrepreneur?" is the wrong question, Entrepreneurship Theory and Practice 13, 47-68. 
Gartner, W.B., 1985, A conceptual framework for describing the phenomenon of new venture creation, Academy of Management Review 10, 696-706.

Gartner, W.B., Mitchell, T.R. and K.H. Vesper, 1989, A taxonomy of new business ventures, Journal of Business Venturing 4, 169-186.

Gasse, Y., 1982, Elaborations on the psychology of the entrepreneur. In: Kent, C.A., D.L. Sexton, and K.H. Vesper (eds.), Encyclopedia of Entrepreneurship, Englewood Cliffs, NJ: Prentice-Hall, 5771.

Gelderen, M. van, 2000, Enterprising behaviour of ordinary people, European Journal of Work and Organizational Psychology 9 (1), 81-88.

Gimeno, J., Folta, T.B., Cooper, A.C. and C.Y. Woo, 1997, Survival of the fittest? Entrepreneurial human capital and the persistence of underperforming firms, Administrative Science Quarterly 42 (4), 750-783.

Goffee, R. and R. Scase, 1985, Women in Charge: The Experiences of Female Entrepreneurs, London: George Allen and Unwin.

Greiner, L.E., 1972, Evolution and revolution as organizations grow, Harvard Business Review 50, $37-$ 46.

Haemmerlie, F.M. and R.L. Montgomery, 1987, Self-perception theory, salience of behavior, and a control-enhancing program for the elderly, Journal of Social and Clinical Psychology 5 (3), 313329.

Healy, M. and C. Perry, 2000, Comprehensive criteria to judge validity and reliability of qualitative research within the realism paradigm, Qualitative Market Research: An International Journal 3 (3), 118-126.

Hébert, R.F. and A.N. Link, 1989, In search of the meaning of entrepreneurship, Small Business Economics 1, 39-49.

Hisrich, R. and C.G. Brush, 1983, The woman entrepreneur: implications of family, educational and ocupational experience, Frontiers of Entrepreneurship Research, Wellesley, MA: Babson College, $255-270$.

Hornaday, J.A., 1992, Thinking about entrepreneurship: a fuzzy set approach, Journal of Small Business Management 30 (4), 12-23.

Howell, J.M. and C.A. Higgins, 1990, Champions of technological innovation, Administrative Science Quarterly 35, 317-341.

Hull, D., Bosley, J. and G. Udell, 1980, Renewing the hunt for the heffalump: identifying potential entrepreneurs by personality characteristics, Journal of Small Business Management 18 (1), 11-18.

Hulshoff, H.E., Kerste, R. and D. Snel, 2001, Jonge ondernemingen in 2000 (Young firms in 2000), Zoetermeer: EIM Business and Policy Research.

James, W., 1890, The Principles of Psychology (vol. 1/2), New York: Holt.

James, W., 1950, The Priciples of Psychology, (reprint, original publication in 1890) New York: Dover.

James, L.R. and J.M. Brett, 1984, Mediators, moderators, and tests for mediation, Journal of Applied Psychology, 69 (2), 307-321.

Kalleberg, A.L. and K.T. Leicht, 1991, Gender and organizational performance: determinants of small business survival and success, Academy of Management Journal 34 (1), 136-161.

Kaufmann, P.J., 1999, Franchising and the choice of self-employment, Journal of Business Venturing 14 (4), 345-362.

Kaufmann, P.J. and R.P. Dant, 1998, Franchising and the domain of entrepreneurship research, Journal of Business Venturing 14, 5-16.

Kirchoff, B.A., 1994, Entrepreneurship and Dynamic Capitalism, Wetport, Conn: Praeger Publishers.

Kirzner, I.M., 1979, Perception, Opportunity and Profit, Chicago: University of Chicago Press.

Knight, F.H., 1921, Risk, Uncertainty and Profit, (ed. G.J. Stigler), Chicago: University of Chicago Press. 
Krueger, N., 1993, The impact of prior entrepreneurial exposure on perceptions of new venture feasibility and desirability, Entrepreneurship Theory and Practice 18 (1), 5-21.

Krueger, N.F. Jr. and D.V. Brazeal, 1994, Entrepreneurial potential and potential entrepreneurs, Entrepreneurship Theory and Practice 18 (3), 91-104.

LaNoue, J.B. and R.C. Curtis, 1985, Improving women's performance in mixed-sex situations by effort attributions, Psychology of Women Quarterly 9, 337-356.

Laverie, D.A., Kleine III, R.E. and S. Schultz Kleine, 2002, Reexamination and extension of Kleine, Kleine and Kernan's social identity model of mundane consumption: the mediating role of the appraisal process (Re-Inquiries), Journal of Consumer Research 28, 659-669.

Lindeman, M., Sundvik, L. and P. Rouhiainen, 1995, Underestimation or overestimation of self-person variables and self-assessment accuracy in work settings, Journal of Social Behaviour and Personality 10, 123-134.

Low, M. and I.C. MacMillan, 1988, Entrepreneurship: past research and future challenges, Journal of Management 14 (2), 139-161.

Lumpkin, G.T. and G.G. Dess, 1996, Clarifying the entrepreneurial orientation construct and linking it to performance, Academy of Management Review 21 (1), 135-172.

Manolova, T.S., Brush, C.G., Edelman, L.F. and P.G. Greene, 2002, Internationalization of small firms: personal factors revisited, International Small Business Journal 20 (1), 9-31.

Markus, H. and S. Kitayama, 1991, Culture and the self: implications for cognition, emotion, and motivation, Psychological Review 98, 224-253.

Masters, R. and R. Meier, 1988, Sex differences and risk taking propensity of entrepreneurs, Journal of Small Business Management 26 (1), 31-35.

McCLelland, D.C., 1961, The Achieving Society, Princeton, NJ: Van Nostrand.

McClelland, D.C., 1965, Need achievement and entrepreneurship: a longitudinal study, Journal of Personality and Social Psychology 1, 389-392.

Nerkar, A.A., R.G. McGrath and I.C. MacMillan, 1996, Three facets of satisfaction and their influence on the performance of innovation teams, Journal of Business Venturing, 11 (3), 167-89.

NFWBO, 1996, Research Findings, Silver Spring, MD: National Foundation of Women Business Owners.

OECD, 1998, Women Entrepreneurs in Small and Medium Enterprises, OECD Conference Paris 1997, OECD, Paris.

Parsons, J.E., Meece, J.L., Adler, T.F. and C.M. Kaczala, 1982, Sex differences in attributions and learned helplessness, Sex Roles 8, 421-432.

Perry, C., MacArthur, R. Meredith, G. and B. Cunnington, 1986, Need for achievement and locus of control of Australian small business owner-managers and super-entrepreneurs, International Small Business Journal 4, 55-64.

Polyani, M., 1966, The Tacit Dimension, Garden City, New York: Anchor Books.

Powell, G.N., Butterfield, D.A. and J.D. Parent, 2002, Gender and managerial stereotypes: have the times changed? Journal of Management 28 (2), 177-193.

Powell, G.N. and D.A. Butterfield, 1989, The "good manager": did androgyny fare better in the 1980s? Group and Organization Studies 14 (2), 216-233.

Powell, G.N. and D.A. Butterfield, 1979, The "good manager": masculine or androgynous? Academy of Management Journal 22, 395-403.

Praag, M.C. van, 1999, Some classic views on entrepreneurship, De Economist 147 (3), 311-335.

Reynolds, P.D., Bygrave, W.D., Autio, E., Cox, L.W. and M. Hay, 2002, Global Entrepreneurship Monitor 2002 Executive Report, Babson College, London Business School and Kauffman Foundation.

Reynolds, P.D., Storey, D.J. and S.M. Camp, 1999, Global Entrepreneurship Monitor: 1999 Executive Report, Babson College, London Business School and Kauffman Center for Entrepreneurial Leadership. 
Reynolds, P.D., 1997, Participation in the entrepreneurial process: estimates for US households, Briefing Report, Entrepreneurial Research Consortium, Babson College, Wellesley, MA.

Robak, R.W., 2001, Self-definition in psychotherapy: is it time to revisit self-perception theory?, North American Journal of Psychology 3 (3), 529-534.

Rosa, P., Carter, S. and D. Hamilton, 1996, Gender as a determinant of small business performance: Insights from a British study, Small Business Economics 8 (4), 463-478.

Rosenthal, P., Guest, D. and R. Peccei, 1996, Gender differences in managers' causal explanations for their work performance: a study in two organizations, Journal of Occupational and Organizational Psychology 69, 145-151.

Rotter, J.B., 1966, Generalized expectancies for internal versus external control of reinforcement, $P s y$ chological Monographs: General and Applied 80 (1), no. 609.

Samuelsson, M., 2001, Modeling the nascent venture opportunity exploitation process across time. In: W.D. Bygrave, E.Autio, C.G. Brush, P. Davidsson, P.G. Green, P.D. Reynolds \& H.J. Sapienza (eds.), Frontiers of Entrepreneurship Research 2001, Wellesley, MA: Babson College, 66-79.

Schein, V., 1975, Relationships between sex role stereotypes and requisite management characteristics among female managers, Journal of Applied Psychology 60, 340-344.

Schein, V., 1973, The relationship between sex role stereotypes and requisite management characteristics, Journal of Applied Psychology 57, 95-100.

Schnall, S., Abrahamson, A. and J.D. Laird, 2002, Premenstrual syndrome and misattribution: a selfperception, individual differences perspective, Basic and Applied Social Psychology 24 (3), 215228.

Schön, D.A., 1963, Champions for radical new inventions, Harvard Business Review 41, 77-86.

Schumpeter, J.A., 1934, The Theory of Economic Development, Cambridge, MA: Harvard University.

Sexton, D.L. and N. Bowman-Upton, 1990, Female and male entrepreneurs: psychological characteristics and their role in gender-related discrimination, Journal of Business Venturing 5, 29-36.

Sexton, D.L. and N. Bowman, 1985, The entrepreneur: a capable executive and more, Journal of Business Venturing 1 (1), 129-140.

Sexton, D.L. and N. Bowman, 1986, Validation of a personality index: comparative entrepreneurial analysis of female entrepreneurs, managers, entrepreneurship students and business students. In: Ronstadt, R., Hornaday, J.A., Peterson, R. and K.H. Vesper (eds.), Frontiers of Entrepreneurship Research, Wellesley, MA: Babson College, 40-51.

Shackle, G.L.S., 1979, Imagination and the Nature of Choice, Edinburgh: Edinburgh University Press.

Shane, S.A., 1994, Are champions different from non-champions?, Journal of Business Venturing 9, 397-421.

Shane, S.A. and F. Hoy, 1996, Franchising: a gateway to cooperative entrepreneurship, Journal of Business Venturing 11 (5), 325-327.

Smith , K., Gannon, M., Grimm, C. and T. Mitchell, 1988, Decision-making behavior in smaller entrepreneurial and larger professionally managed firms, Journal of Business Venturing 3, 223-232.

Stevenson, H.H. and J.C. Jarillo, 1990, A paradigm of entrepreneurship: entrepreneurial management, Strategic Management Journal 11, 17-27.

Stewart, W.H. Jr., Watson, W.E., Carland, J.C. and W. Carland, 1999, A proclivity for entrepreneurship: a comparison of entrepreneurs, small business owners, and corporate managers, Journal of Business Venturing 14 (2), 189-214.

Stewart, W.H. and P.L. Roth, 2001, Risk propensity differences between entrepreneurs and managers: a meta-analysis review, Journal of Applied Psychology 86 (1), 145-153.

Stigter, H.W., 1999, Vrouwelijk ondernemerschap in Nederland 1994-1997 (Female entrepreneurship in the Netherlands 1994-1997), Zoetermeer: EIM Business and Policy Research.

Stopford, J.M. and C.W.F. Baden-Fuller, 1994, Creating corporate entrepreneurship, Strategic Management Journal 15 (7), 521-536.

Storey, D.J., 1994, Understanding the Small Business Sector, London/New York: Routledge. 
Triandis, H.C., 1989, The self and social behavior in differing cultural contexts, Psychological Review 96, 506-520.

U.S. Small Business Administration, 1995, The Third Millennium: Small Business and Entrepreneurship in the Twenty-First Century, Washington DC: U.S. Small Business Administration.

Uranowitz, S.W., 1975, Helping and self-attributions: a field experiment, Journal of Personality and Social Psychology 31 (5), 852-854.

Uxem, F. van and J. Bais, 1996, Het starten van een bedrijf. Ervaringen van 2000 starters (Starting a firm. Experiences of 2000 starters), Zoetermeer: EIM Business and Policy Research.

Venkataraman, S., MacMillan, I.C. and R.G. McGrath, 1992, Progress in research on corporate venturing, in: D.L. Sexton and J.D. Kasarda (eds.), The State and Art of Entrepreneurship, Boston; PWSKent, 487-519.

Verheul, I., Risseeuw, P.A. and G. Bartelse, 2002, Gender differences in strategy and human resource management: the case of Dutch real estate brokerage, International Small Business Journal 20 (4), 443-476.

Verheul, I. and A.R. Thurik, 2001, Start-up capital: differences between male and female entrepreneurs: Does gender matter? Small Business Economics 16 (4), 329-345.

Vesper, K.H., 1980, New Venture Strategies, Englewood Cliffs, NJ: Prentice Hall.

Vesper, K.H., 1999, Unfinished Business (Entrepreneurship) of the $20^{\text {th }}$ Century, paper presented at the USASBE conference, San Diego, California, January 1999

Watkins, J.M. and D.S. Watkins, 1983, The female entrepreneur: her background and determinants of business choice - some British data. In: Hornaday, J.A., J. Timmons and K.H. Vesper (eds.), Frontiers of Entrepreneurship Research, Wellesley, MA: Babson College, 271-288.

Watson, J., 2002, Comparing the performance of male- and female-controlled businesses: relating outputs to inputs, Entrepreneurship Theory and Practice 26 (3), 91-100.

Weiner, M.J., 1974, Cognitive dissonance or self perception, Personality and Social Psychology Bulletin 1 (1), 144-146.

Wennekers, A.R.M. and A.R. Thurik, 1999, Linking entrepreneurship and economic growth, Small Business Economics 13 (1), 27-55.

Williams, D.L., 1998, Why do entrepreneurs become franchisees? An empirical analysis of organizational choice, Journal of Business Venturing 14 (1), 103-124.

Wohlers, A.J. and M. London, 1989, Ratings of managerial characteristics: evaluation difficulty, coworker agreement and self-awareness, Personnel Psychology 42, 235-261.

Wood, R. and A. Bandura, 1989, Social cognitive theory of organizational management, Academy of Management Review 14 (3), 361-384. 


\section{APPENDIX}

Description of Variables

\begin{tabular}{|c|c|}
\hline Name of variable & Description of variable \\
\hline Entrepreneurial Self-Image & $\begin{array}{l}\text { The extent to which an individual perceives of him- or } \\
\text { herself as an entrepreneur. Question: would you call } \\
\text { yourself an entrepreneur? } \\
(1=\text { 'no', } 2=\text { 'don't think so', } 3=\text { 'maybe', } 4=\text { 'possibly', } 5=\text { 'definitely') }\end{array}$ \\
\hline Gender & $\begin{array}{l}\text { Whether an individual is male of female. } \\
(\text { male }=0 \text { and female }=1)\end{array}$ \\
\hline Business Accomplishments ${ }^{a}$ & $\begin{array}{l}\text { Respondents were asked the following: "Please check } \\
\text { any of the following business accomplishments you } \\
\text { have done in the past or are currently doing". }\end{array}$ \\
\hline Founder ${ }^{\mathrm{b}}$ & Created a new business from scratch? $($ no $=0$, yes $=1)$ \\
\hline Franchisee $^{\mathrm{b}}$ & Started a franchise business $($ no $=0$, yes $=1)$ \\
\hline Acquirer ${ }^{b}$ & Acquired an on-going concern? $($ no $=0$, yes $=1)$ \\
\hline Runner $^{\mathrm{b}}$ & $\begin{array}{l}\text { Managed a small to mid-sized business beyond start- } \\
\text { up? (no }=0 \text {, yes }=1 \text { ) }\end{array}$ \\
\hline Take-Off Artist $^{\mathrm{b}}$ & $\begin{array}{l}\text { Steered a company into a high growth trajectory? } \\
(\text { no }=0, \text { yes }=1)\end{array}$ \\
\hline Turnaround Artist ${ }^{\mathrm{b}}$ & Saved a failing company? $($ no $=0$, yes $=1)$ \\
\hline Intrapreneur ${ }^{\mathrm{b}}$ & $\begin{array}{l}\text { Led an effort to create a business unit within an estab- } \\
\text { lished company? }(\text { no }=0 \text {, yes }=1)\end{array}$ \\
\hline Innovator $^{b}$ & $\begin{array}{l}\text { Made something new happen (e.g. new product, pro- } \\
\text { gram) other than a new business unit or new company? } \\
(\text { no }=0 \text {, yes }=1)\end{array}$ \\
\hline Industry Captain ${ }^{\mathrm{b}}$ & Ran a large company? $($ no $=0$, yes $=1)$ \\
\hline Champion ${ }^{\mathrm{b}}$ & $\begin{array}{l}\text { Supported subordinate innovator(s) or intrapreneur(s)? } \\
(\text { no }=0, \text { yes }=1)\end{array}$ \\
\hline Owner & Owned a major part of a business? $($ no $=0$, yes $=1)$ \\
\hline Service Provider & $\begin{array}{l}\text { Worked with / assisted entrepreneurs as a service pro- } \\
\text { vider? }(\text { no }=0 \text {, yes }=1)\end{array}$ \\
\hline Family Business & $\begin{array}{l}\text { Worked as member of a family business ( } 2 \text { or more } \\
\text { family members, including yourself, active in the busi- } \\
\text { ness)? (no }=0 \text {, yes }=1 \text { ) }\end{array}$ \\
\hline
\end{tabular}

Control Variables

\begin{tabular}{|c|c|}
\hline Age & $\begin{array}{l}\text { Age of the respondent }(1=18-22 ; 2=23-27 ; 3=28-35 ; 4=36-45 ; \\
5=46-55 ; 6=56-65 ; 7=\text { over } 65)\end{array}$ \\
\hline Education Level & $\begin{array}{l}\text { What is the highest educational level attained? }(0=\text { no } \\
\text { degree; } 1=\text { bachelor; } 2=\text { masters; } 3=\mathrm{PhD} \text {.) }\end{array}$ \\
\hline Business Degree & $\begin{array}{l}\text { Does the respondent have a business degree? (no }=0 \text {, yes } \\
=1 \text { ) }\end{array}$ \\
\hline Introduction Course & $\begin{array}{l}\text { Has the respondent followed an introduction course in } \\
\text { entrepreneurship? (no }=0 \text {, yes }=1)\end{array}$ \\
\hline
\end{tabular}

\footnotetext{
${ }^{a}$ For this group of questions respondents were instructed as follows: "The following describe various types of business accomplishments. Please check any of the following that you have done in the past or are currently doing".

${ }^{\mathrm{b}}$ Derived from Vesper (1999).
} 
Table 1: Vesper's Entrepreneurial Typology

\begin{tabular}{|l|l|}
\hline Name/ type & Entrepreneurial activity \\
\hline Starter & enters an independent business by creating a new one \\
\hline Acquirer & $\begin{array}{l}\text { enters an independent business by acquiring an ongo- } \\
\text { ing concern }\end{array}$ \\
\hline Runner & manages a small to medium business beyond start-up \\
\hline Take-Off Artist & steers a company into a high-growth trajectory \\
\hline Turnaround Artist & saves a failing company \\
\hline Innovator & makes something new happen that is not a company \\
\hline Champion & supports innovator \\
\hline Intrapreneur & $\begin{array}{l}\text { takes initiative for business unit creation inside an } \\
\text { established business }\end{array}$ \\
\hline Industry Captain & runs a big business \\
\hline
\end{tabular}

Table 2: Ranking Business Accomplishments According to Degree of Entrepreneurship

\begin{tabular}{|c|c|c|c|c|c|}
\hline \multirow[b]{2}{*}{ Business Accomplishments } & \multicolumn{3}{|c|}{ Entrepreneurial Characteristics } & \multirow[b]{2}{*}{ Score } & \multirow[b]{2}{*}{$\operatorname{Rank}$} \\
\hline & $\begin{array}{l}\text { Opportunity } \\
\text { Perception }\end{array}$ & Risk-Taking & Innovation & & \\
\hline Founder ${ }^{\mathrm{a}}$ & $\begin{array}{l}4 \\
\text { high }\end{array}$ & $\begin{array}{l}4 \\
\text { high }\end{array}$ & $\begin{array}{l}4 \\
\text { high }\end{array}$ & 12 & 1 \\
\hline Innovator & $\begin{array}{l}4 \\
\text { high }\end{array}$ & $\begin{array}{l}2 \\
\text { medium }\end{array}$ & $\begin{array}{l}4 \\
\text { high }\end{array}$ & 10 & 2 \\
\hline Intrapreneur & $\begin{array}{l}4 \\
\text { high }\end{array}$ & $\begin{array}{l}2 \\
\text { medium }\end{array}$ & $\begin{array}{l}3 \\
\text { medium/high }\end{array}$ & 9 & 4-tie \\
\hline Take-Off Artist & $\begin{array}{l}4 \\
\text { high }\end{array}$ & $\begin{array}{l}2 \\
\text { medium }\end{array}$ & $\begin{array}{l}3 \\
\text { medium/high }\end{array}$ & 9 & 4-tie \\
\hline Acquirer & $\begin{array}{l}3 \\
\text { medium/high }\end{array}$ & $\begin{array}{l}3 \\
\text { medium/high }\end{array}$ & $\begin{array}{l}2 \\
\text { medium }\end{array}$ & 8 & 7-tie \\
\hline Franchisee & $\begin{array}{l}3 \\
\text { medium/high }\end{array}$ & $\begin{array}{l}3 \\
\text { medium/high }\end{array}$ & $\begin{array}{l}2 \\
\text { medium }\end{array}$ & 8 & 7-tie \\
\hline Runner & $\begin{array}{l}3 \\
\text { medium/high }\end{array}$ & $\begin{array}{l}2 \\
\text { medium }\end{array}$ & $\begin{array}{l}3 \\
\text { medium/high }\end{array}$ & 8 & 7-tie \\
\hline Turnaround Artist & $\begin{array}{l}3 \\
\text { medium/high }\end{array}$ & $\begin{array}{l}2 \\
\text { medium }\end{array}$ & $\begin{array}{l}2 / 3 \\
\text { medium- } \\
\text { medium/high }\end{array}$ & 7.5 & 8 \\
\hline Champion & $\begin{array}{l}3 \\
\text { medium/high }\end{array}$ & $\begin{array}{l}1 / 2 \\
\text { low-medium }\end{array}$ & $\begin{array}{l}2 \\
\text { medium }\end{array}$ & 6.5 & 9 \\
\hline Industry Captain & $\begin{array}{l} \\
\text { medium }\end{array}$ & $\begin{array}{l}1 \\
\text { low }\end{array}$ & $\begin{array}{l}1 \\
\text { low }\end{array}$ & 4 & 10 \\
\hline Service Provider & $\begin{array}{l}2 \\
\text { medium }\end{array}$ & $\begin{array}{l}1 \\
\text { low }\end{array}$ & $\begin{array}{l}1 \\
\text { low }\end{array}$ & 4 & 10 \\
\hline Ownership & indeterminate & $\begin{array}{l}4 \\
\text { high }\end{array}$ & indeterminate & $?$ & $?$ \\
\hline Family Business & indeterminate & indeterminate & indeterminate & $?$ & $?$ \\
\hline
\end{tabular}

${ }^{\text {a }}$ We choose to use the term Founder instead of Vesper's Starter as we make a distinction between starting a business which is not a franchise (Founder) and starting a franchise firm (Franchisee) in this study's analyses. 
Table 3: Ranking Business Accomplishments according to Expert Panel ( $\mathrm{n}=162)$

\begin{tabular}{|c|c|c|c|c|c|}
\hline Business Accomplishment & Mean & $\begin{array}{l}\text { Std. de- } \\
\text { viation }\end{array}$ & $\begin{array}{l}\text { \% rated } \\
\text { '1', '2' by } \\
\text { experts }\end{array}$ & $\begin{array}{l}\text { \% rated } \\
\text { ' } 1 \text { ' by } \\
\text { experts }\end{array}$ & $\begin{array}{l}\text { Literature } \\
\text { ranking } \\
\text { (Table 2) } \\
\end{array}$ \\
\hline 1. Founder & 1.27 & 0.62 & 93.8 & 80.2 & 1 \\
\hline 2. Intrapreneur & 1.95 & 0.99 & 73.9 & 40.4 & 4-tie \\
\hline 3. Innovator & 2.06 & 1.01 & 70.6 & 34.4 & 2 \\
\hline 4. Take-Off Artist & 2.14 & 1.01 & 67.7 & 29.7 & 4-tie \\
\hline 5. Franchisee & 2.23 & 1.11 & 62.7 & 31.6 & 7-tie \\
\hline 6. Runner & 2.37 & 1.03 & 55.9 & 21.7 & 7-tie \\
\hline 7. Turnaround Artist & 2.46 & 1.08 & 51.9 & 21.5 & 8 \\
\hline 8. Acquirer & 2.58 & 1.21 & 50.3 & 21.7 & 7-tie \\
\hline 9. Family Business & 2.82 & 1.20 & 36.9 & 17.2 & $?$ \\
\hline 10. Champion & 2.97 & 1.15 & 21.3 & 13.0 & 9 \\
\hline 11. Owner & 3.12 & 1.13 & 19.6 & 9.2 & $?$ \\
\hline 12. Industry Captain & 3.13 & 1.11 & 24.2 & 8.1 & 10 \\
\hline 13. Service Provider & 3.31 & 1.14 & 19.0 & 9.5 & 11 \\
\hline
\end{tabular}

a: '1'=definitely; '2'=probably. 


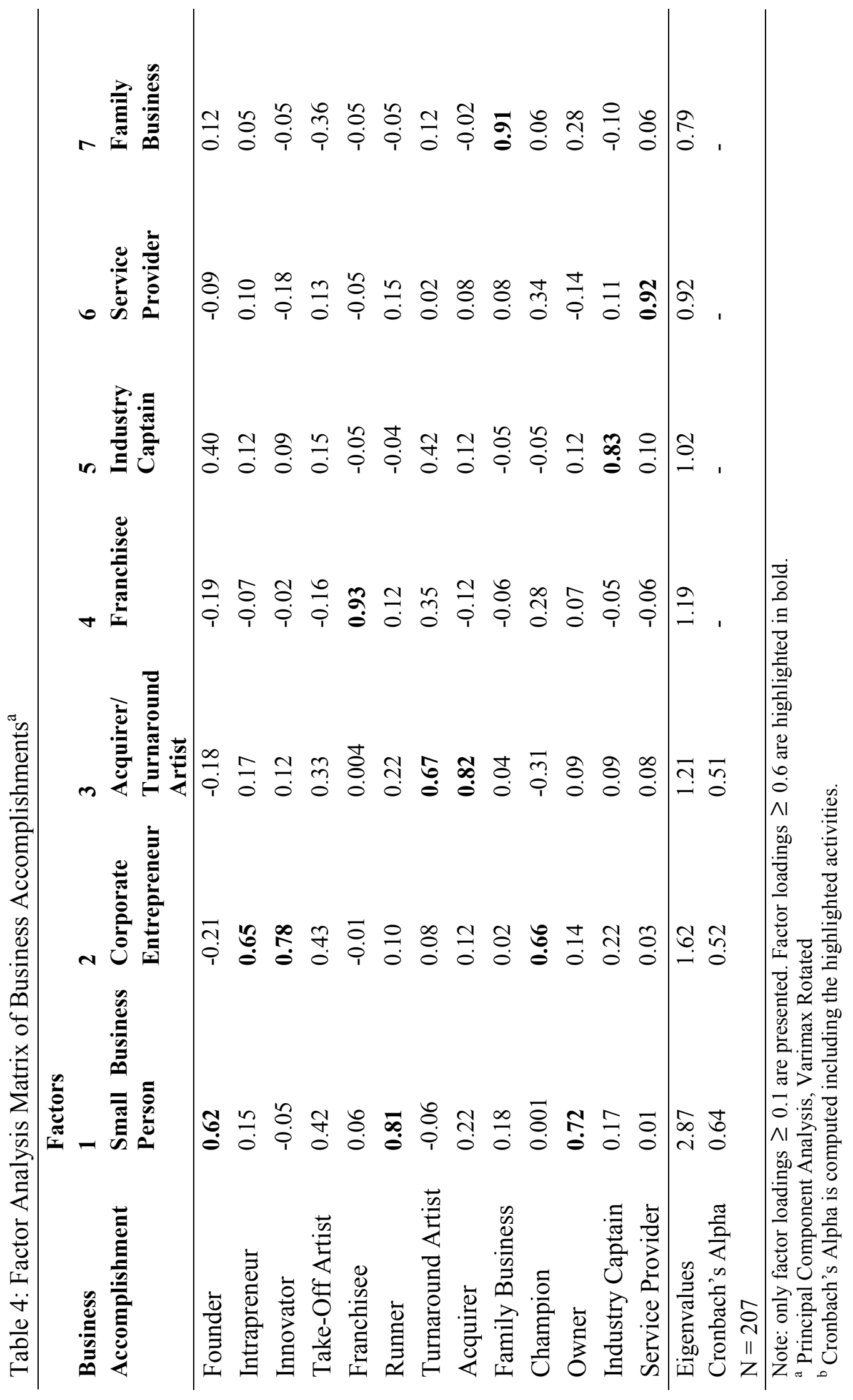




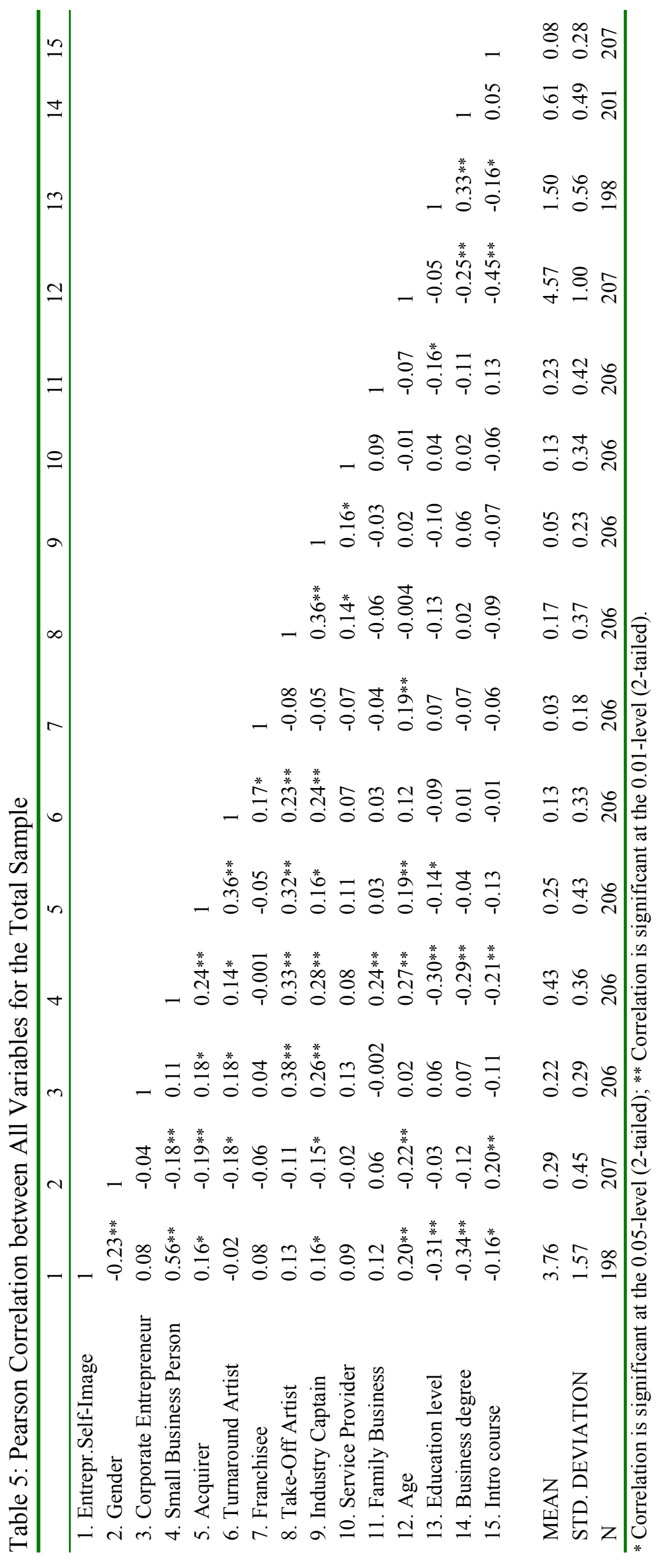




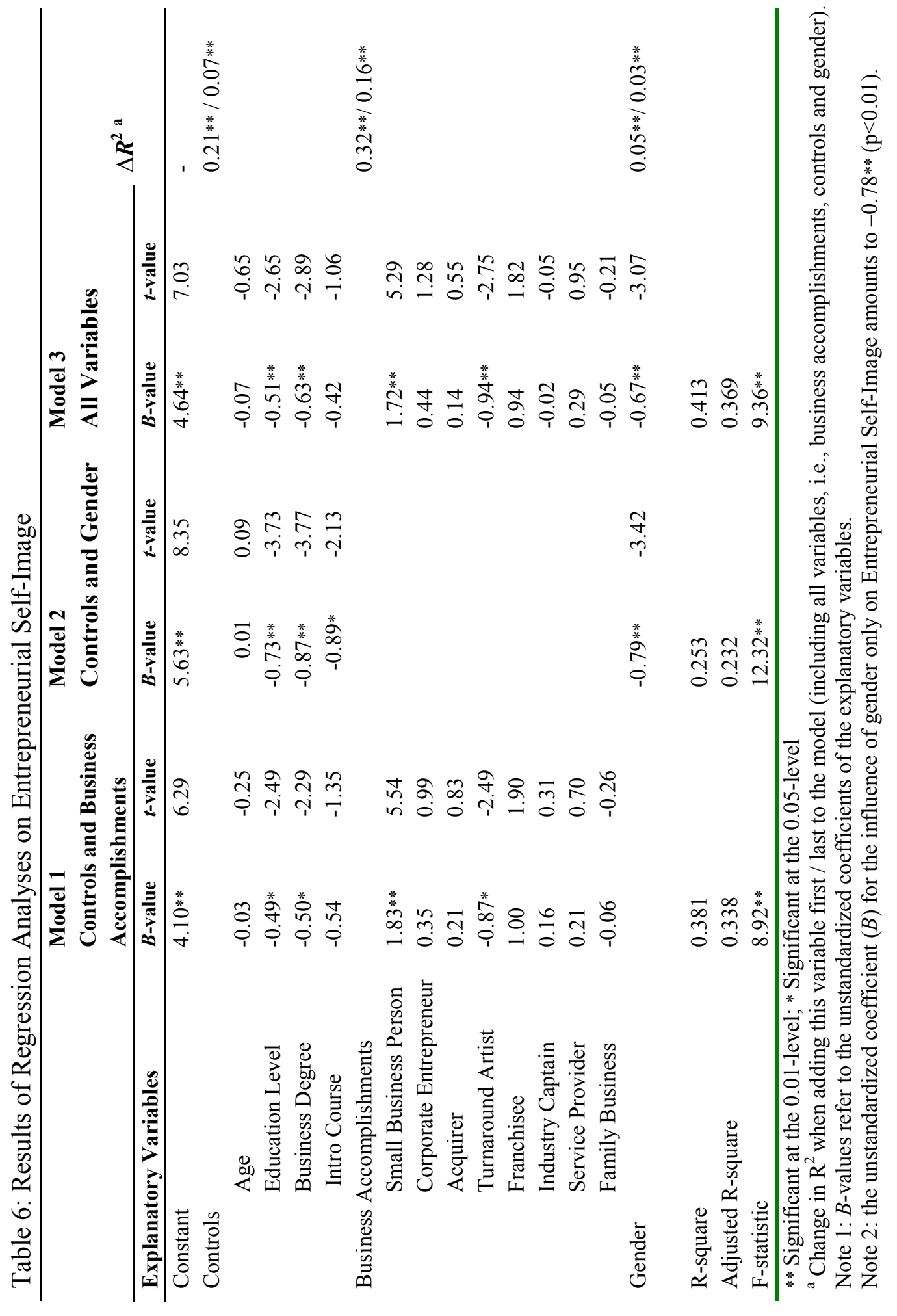


Figure 1: Proposed Model: Influences on Entrepreneurial Self-Image

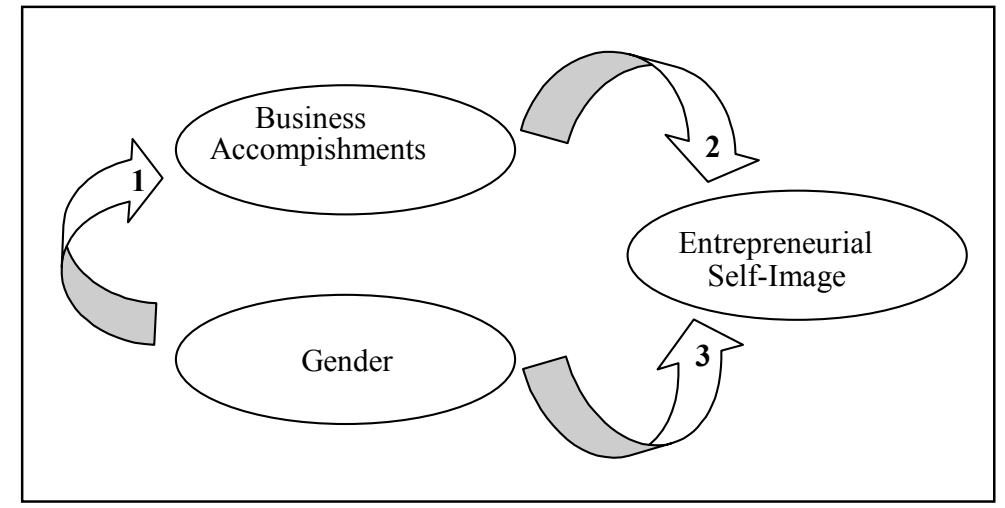

